\title{
ESGO/ISUOG/IOTA/ESGE Consensus Statement on preoperative diagnosis of ovarian tumours
}

\begin{abstract}
The European Society of Gynaecological Oncology (ESGO), the International Society of Ultrasound in Obstetrics and Gynecology (ISUOG), the International Ovarian Tumour Analysis (IOTA) group and the European Society for Gynaecological Endoscopy (ESGE) jointly developed clinically relevant and evidence-based statements on the preoperative diagnosis of ovarian tumours, including imaging techniques, biomarkers and prediction models. ESGO/ISUOG/IOTA/ESGE nominated a multidisciplinary international group, including expert practising clinicians and researchers who have demonstrated leadership and expertise in the preoperative diagnosis of ovarian tumours and management of patients with ovarian cancer (19 experts across Europe). A patient representative was also included in the group. To ensure that the statements were evidence-based, the current literature was reviewed and critically appraised.

Preliminary statements were drafted based on the review of the relevant literature. During a conference call, the whole group discussed each preliminary statement and a first round of voting was carried out. Statements were removed when a consensus among group members was not obtained. The voters had the opportunity to provide comments/suggestions with their votes. The statements were then revised accordingly. Another round of voting was carried out according to the same rules to allow the whole group to evaluate the revised version of the statements. The group achieved consensus on 18 statements.

This Consensus Statement presents these ESGO/ISUOG/IOTA/ESGE statements on the preoperative diagnosis of ovarian tumours and the assessment of carcinomatosis, together with a summary of the evidence supporting each statement.
\end{abstract}

\section{Introduction}

The accurate characterization of newly diagnosed adnexal lesions is of paramount importance to define appropriate treatment pathways. Patients with masses that are suspicious for malignancy should be referred to a gynaecological oncology centre, in order to receive specialist care, as per the definitions of the European Society of Gynaecological Oncology (ESGO) (Querleu et al., 2017) and national and international recommendations and guidelines. For a non-gynaecological primary tumour, patients need to be referred to an appropriate specialist, while patients with benign lesions may be followed up and treated conservatively or may be suitable for less radical surgical treatment, depending on the clinical context (du Bois et al., 2009; Elit et al., 2008; Engelen et al., 2006; Froyman et al., 2019;
Vernooij et al., 2007; Woo et al., 2012). Treatment decision-making processes should be based on a combination of the patient's overall clinical picture, symptoms, preferences, previous medical and surgical history, tumour markers and clinical and radiological findings. A single diagnostic modality alone should not determine the patient's journey.

The ESGO, the International Society of Ultrasound in Obstetrics and Gynecology (ISUOG), the International Ovarian Tumour Analysis (IOTA) group and the European Society for Gynaecological Endoscopy (ESGE) have, jointly, developed clinically relevant and evidencebased statements on the preoperative diagnosis of ovarian tumours and assessment of disease spread, including imaging techniques, biomarkers and predictive models. Neither screening and follow-up modalities, nor economic analysis of the imaging

This paper is being published simultaneously and jointly, in International Journal of Gynecological Cancer and Ultrasound in Obstetrics \& Gynecology and Facts, Views \& Vision in ObGyn ${ }^{\circ} 2021$, by the European Society of Gynecological Oncology (ESGO), the International Society of Ultrasound in Obstetrics and Gynecology (ISUOG), the International Ovarian Tumour Analysis (IOTA) group and the European Society for Gynaecological Endoscopy (ESGE). All rights reserved. 
techniques, biomarkers and prediction models addressed herein, are included within the remit of this Consensus Statement.

\section{Responsibilities}

The present series of statements form a consensus of the authors regarding their currently accepted approaches for the preoperative diagnosis of ovarian tumours and assessment of disease spread, based on the available literature and evidence. Any clinician applying or consulting these statements is expected to use independent medical judgment in the context of individual clinical circumstances to determine all patients' care and treatment. These statements are presented without any warranty regarding their content, use or application and the authors disclaim any responsibility for their application or use in any way.

\section{Methods}

This Consensus Statement on the preoperative diagnosis of ovarian tumours and assessment of disease spread was developed using an eight-step process, chaired by Professors Christina Fotopoulou and Dirk Timmerman (Figure 1). Aiming to assemble a multidisciplinary international group, ESGO/ISUOG/IOTA/ESGE nominated 19 practising clinicians and researchers who have demonstrated leadership and expertise in the preoperative diagnosis of ovarian tumours and clinical management of ovarian cancer patients through research, administrative responsibilities, and/or committee membership (including eight members of ESGO, five members of ISUOG, four members of IOTA and two members of ESGE).
These experts included seven gynaecologists with special interest in ultrasonography, two radiologists and 10 gynaecological oncologists. They did not represent the societies from which they were selected, and were asked to base their decisions on their own experience and expertise. Also included in the group was a patient representative, who is Chair of the Clinical Trial Project of the European Network of Gynaecological Cancer Advocacy Groups, ENGAGe. An initial conference call, including the whole group, was held to facilitate introductions, as well as to review the purpose and scope of this Consensus Statement.

To ensure that the statements were evidencebased, the current literature was reviewed and critically appraised. Thus, a systematic literature review of relevant studies published between 1 May 2015 and 1 May 2020 was carried out using the MEDLINE database (Appendix 1). The literature search was limited to publications in the English language. Priority was given to highquality systematic reviews, meta-analyses and validating cohort studies, although studies with lower levels of evidence were also evaluated. The search strategy excluded editorials, letters and case reports. The reference list of each identified article was reviewed for other potentially relevant articles. Final results of the literature search were distributed to the whole group, including electronic full-text versions of each article. F. Planchamp provided the methodology and medical writing support for the entire process, and did not participate in voting for statements.

The chairs were responsible for drafting preliminary statements based on the review of the relevant literature. These were then sent to the multidisciplinary international group prior to

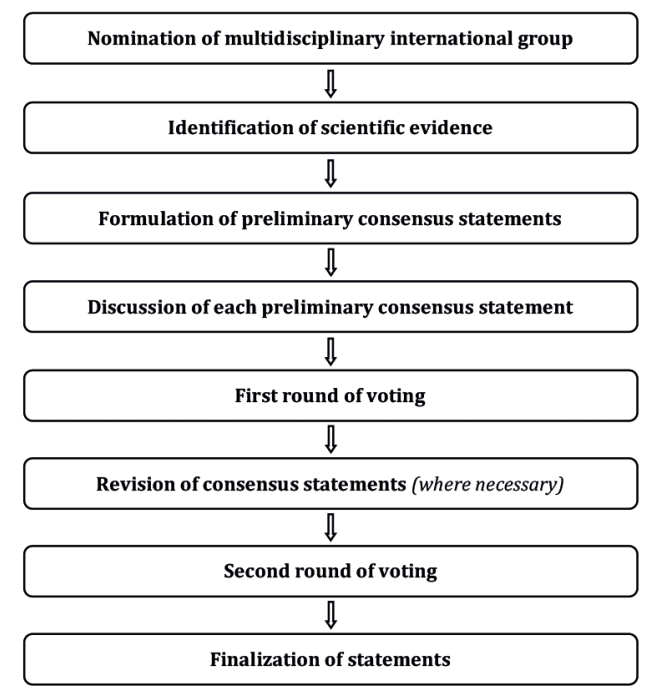

Figure 1: Eight-step process for development of Consensus Statement on the preoperative diagnosis of ovarian tumours and assessment of disease spread. 
a second conference call. During this conference call, the whole group discussed each preliminary statement and a first round of binary voting (agree/disagree) was carried out for each potential statement. All 20 participants took part in each vote, but they were permitted to abstain from voting if they felt they had insufficient expertise to agree/disagree with the statement or if they had a conflict of interest that could be considered to influence their vote. Statements were removed when a consensus among group members was not obtained. The voters had the opportunity to provide comments/suggestions with their votes. The chairs then discussed the results of this first round of voting and revised the statements if necessary. The voting results and the revised version of the statements were again sent to the whole group and another round of binary voting was organized, according to the same rules, to allow the whole group to evaluate the revised version of the statements. The statements were finalized based on the results of this second round of voting. The group achieved consensus on 18 statements. In this Consensus Statement, we present a summary of the supporting evidence, the finalised series of statements, and their levels of evidence and grades.

\section{Results}

\section{General remarks}

Even though the test performance of any biochemical or radiological diagnostic test appears to increase after excluding borderline ovarian tumours and non-gynaecological primary tumours, such as of the gastrointestinal tract or breast, we included in our literature assessment studies addressing all types of adnexal tumour, as this is a better reflection of clinical reality.

\section{Ultrasonography}

A transvaginal ultrasound examination is often regarded in clinical practice as the standard firstline imaging investigation for the assessment of adnexal pathology (Kaijser et al., 2014; Meys et al., 2016; Timmerman, 2004; Valentin et al., 2001). The diagnostic accuracy of ultrasonography in differentiating between benign and malignant adnexal masses has been shown to relate to the expertise of the operator (Timmerman et al., 1999; Valentin, 1999; Yazbek et al., 2008). The European Federation of Societies for Ultrasound in Medicine and Biology has published minimum training requirements for gynaecological ultrasound practice in Europe, including standards for theoretical knowledge and practical skills (Education and Practical Standards Committee, European
Federation of Societies for Ultrasound in Medicine and Biology, 2006). These identify three levels of training and expertise. Thus, Level-III (expert) can be attributed to a practitioner who is likely to spend the majority of their time undertaking gynaecological ultrasound and/or teaching, research and development in the field. A Level-II practitioner should have undertaken at least 2000 gynaecological ultrasound examinations. The training required to attain this level of practice would usually be gained during a period of expert ultrasound training, which may be within, or after completion of, a specialist training program. To maintain competence at Level-II, practitioners should perform at least 500 examinations each year. A Level-I practitioner should have performed a minimum of 300 examinations under the supervision of a Level-II practitioner or an experienced Level-I practitioner with at least 2 years' regular practical experience. To maintain Level-I status, the practitioner should perform at least 300 examinations each year. A prospective randomized controlled trial to assess the effect of the quality of gynaecological ultrasonography on the management of patients with suspected ovarian cancer has demonstrated that women with a LevelIII (expert) ultrasound examination undergo significantly fewer unnecessary major procedures and have a shorter inpatient hospital stay compared with those having a Level-II (routine) examination by a sonographer (Yazbek et al., 2008).

Subjective assessment by expert ultrasound examiners has excellent performance to distinguish between benign and malignant ovarian tumours (Meys et al., 2016; Timmerman, 2004; Timmerman et al., 1999; Valentin, 1999; Valentin et al., 2001; Yazbek et al., 2008). In many cases, expert examiners should be able to narrow the diagnosis down further, to a specific histological subtype. The typical pathognomonic ultrasound features of some key histological types have been published in the series, 'Imaging in gynecological disease', in Ultrasound in Obstetrics and Gynecology. The most common and typical findings for each pathology are summarized in Table I.

\section{Risk of malignancy index (RMI) and risk of ovarian malignancy algorithm (ROMA)}

Several attempts have been made to develop more objective ultrasound-based approaches for discriminating between benign and malignant adnexal tumours. These include the risk of malignancy index (RMI), a scoring system based on menopausal status, a transvaginal ultrasound score and serum cancer antigen 125 (CA 125) level (Jacobs et al., 1990). Many studies have demonstrated the diagnostic performance of the 
Table I. - Clinical and ultrasound features typical of different histological subtypes of adnexal tumour.

\begin{tabular}{|c|c|c|c|c|c|c|c|}
\hline Category/Type & Age (years) & Laterality & Appearance & Typical features & Colour score & Image & Ref \\
\hline \multicolumn{8}{|c|}{ Endometriosis-related tumours } \\
\hline Endometrioma & Median, 34 & Uni/bi & $\begin{array}{c}\text { Uni- or } \\
\text { multilocular } \\
(1-4 \text { locules })\end{array}$ & $\begin{array}{c}\text { Ground-glass } \\
\text { content; papillations } \\
\text { in } 10 \% \text {, but most } \\
\text { often without } \\
\text { internal blood flow; } \\
\text { premenopausal } \\
\text { patient; raised } \\
\text { CA } 125 \\
\text { (median, } 44 \mathrm{U} / \mathrm{mL} \text { ) }\end{array}$ & $1 / 2 /(3)$ & & 171 \\
\hline \multicolumn{8}{|l|}{ Benign tumours } \\
\hline \multicolumn{8}{|l|}{$\begin{array}{l}\text { Sex cord-stromal } \\
\text { tumour }\end{array}$} \\
\hline $\begin{array}{l}\text { Fibroma/ } \\
\text { fibrothecoma } \\
(65 \%)\end{array}$ & $\begin{array}{c}\text { Median, } \\
50 ; 65 \% \\
\text { postmenopausal }\end{array}$ & Uni & $\begin{array}{l}\text { Regular round, } \\
\text { oval or slightly } \\
\text { lobulated } \\
\text { solid tumours; } \\
\text { sometimes } \\
\text { multilocular-solid } \\
(15-20 \%)\end{array}$ & $\begin{array}{l}\text { Fan-shaped } \\
\text { shadowing; often, } \\
\text { raised CA } 125 \\
(34 \%) \text { and/or } \\
\text { ascites }\end{array}$ & $(1) / 2 / 3$ & & 172 \\
\hline $\begin{array}{l}\text { Sertoli-cell tumour } \\
\text { (most benign) }\end{array}$ & $\leq 30(75 \%)$ & Uni & $\begin{array}{c}\text { Solid (median } \\
\text { diameter, } 90 \mathrm{~mm} \text { ) }\end{array}$ & $\begin{array}{c}\text { Hormonally } \\
\text { inactive or } \\
\text { oestrogen- } \\
\text { producing } \\
\text { (abnormal bleeding) }\end{array}$ & $3 / 4$ & & 173 \\
\hline $\begin{array}{l}\text { Leydig-cell } \\
\text { tumour (almost all } \\
\text { benign) }\end{array}$ & Median, 58 & Uni & $\begin{array}{c}\text { Solid (median } \\
\text { diameter, } 24 \mathrm{~mm} \text { ) }\end{array}$ & $\begin{array}{c}\text { Endocrine } \\
\text { symptoms ( } 75 \% \\
\text { virilisation); } \\
\text { testosterone/ } \\
\text { androstenedione }\end{array}$ & $3 / 4$ & & 173 \\
\hline \multicolumn{8}{|l|}{ Germ-cell tumour } \\
\hline $\begin{array}{l}\text { Mature cystic } \\
\text { teratoma (dermoid) }\end{array}$ & Median, 33 & Uni (88\%) & $\begin{array}{l}\text { Uni- }(58 \%) \text { or } \\
\text { multilocular } \\
\text { (or uni-/ } \\
\text { multilocular solid) }\end{array}$ & $\begin{array}{c}\text { Mixed } \\
\text { echogenicity/ } \\
\text { white ball and } \\
\text { stripes/shadowing; } \\
\text { CA 19-9 elevated } \\
\text { in 30\% }\end{array}$ & $1 / 2 /(3)$ & & $\dagger$ \\
\hline $\begin{array}{l}\text { Struma ovarii } \\
\text { (entirely or } \\
\text { predominantly } \\
\text { thyroid tissue); 3\% } \\
\text { of all ovarian } \\
\text { teratomas }\end{array}$ & Median, 40 & Uni/bi & $\begin{array}{c}\text { Multilocular/ } \\
\text { multilocular solid; } \\
\text { rarely, papillations; } \\
\text { fluid anechoic or } \\
\text { low-level }\end{array}$ & $\begin{array}{l}\text { 'Struma pearl': } \\
\text { smooth; roundish } \\
\text { solid area; } \\
\text { thyrotoxicosis may } \\
\text { occur }\end{array}$ & $1 / 2 / 3$ & & 174 \\
\hline \multicolumn{8}{|l|}{ Epithelial } \\
\hline $\begin{array}{l}\text { Serous } \\
\text { cystadenoma }\end{array}$ & $40-60$ & Uni $(80-90 \%)$ & $\begin{array}{c}\text { Uni- or } \\
\text { multilocular } \\
\text { (2-10 locules })\end{array}$ & $\begin{array}{l}\text { Anechoic cystic } \\
\text { fluid; often, } \\
\text { papillations without } \\
\text { internal blood flow }\end{array}$ & $1 / 2$ & & $\ddagger$ \\
\hline
\end{tabular}


Table I. - Continued.

\begin{tabular}{|c|c|c|c|c|c|c|c|}
\hline Category/Type & Age (years) & Laterality & Appearance & Typical features & Colour score & Image & Ref \\
\hline $\begin{array}{l}\text { Serous } \\
\text { cystadenofibroma }\end{array}$ & $40-60$ & Uni (84\%) & $\begin{array}{c}\text { Multilocular-solid } \\
(37 \%), \text { unilocular- } \\
\text { solid }(30 \%), \\
\text { multilocular }(19 \%) \\
\text { or unilocular } \\
(13 \%) \text {; median } \\
\text { diameter, } 50- \\
80 \mathrm{~mm}\end{array}$ & $\begin{array}{c}\text { One }(52 \%) \text {, two } \\
(17 \%) \text { or three } \\
(13 \%) \text { papillations; } \\
\text { absent colour } \\
\text { Doppler signals } \\
(80 \%) \text { and shadows } \\
\text { behind papillations } \\
(40 \%)\end{array}$ & $1 / 2$ & & 175 \\
\hline $\begin{array}{l}\text { Mucinous } \\
\text { cystadenoma }\end{array}$ & Median, 50 & Uni (95\%) & $\begin{array}{l}\text { Multilocular }(65 \%) \\
\text { > } 10 \text { locules; } \\
\text { sometimes } \\
\text { unilocular }(18 \%) \text { or } \\
\text { multilocular-solid } \\
(16 \%) ; \text { median } \\
\text { diameter, } 112 \mathrm{~mm}\end{array}$ & $\begin{array}{l}\text { Sometimes } \\
\text { 'honeycomb } \\
\text { nodule' }\end{array}$ & $1 / 2 /(3)$ & & 176 \\
\hline $\begin{array}{l}\text { Brenner tumour } \\
\text { ( } 99 \% \text { benign) }\end{array}$ & $30-70$ & Uni & $\begin{array}{l}\text { Small solid } \\
\text { tumours, } \\
20-80 \mathrm{~mm} ; \\
\text { often extensive } \\
\text { calcifications; } \\
\text { sometimes } \\
\text { multilocular-solid }\end{array}$ & $\begin{array}{c}\text { Small cysts } \\
\text { often seen in } \\
\text { solid tumours; } \\
\text { shadowing; CA } 125 \\
\text { raised in } 10 \%\end{array}$ & $1 / 2 /(3)$ & & 177 \\
\hline \multicolumn{8}{|l|}{ Tumour-like lesions } \\
\hline \multicolumn{8}{|l|}{ Infection } \\
\hline Abscess & $16-50$ & Uni/bi & Uni-/multilocular & $\begin{array}{c}\text { Cogwheel } \\
\text { appearance; mixed } \\
\text { echogenicity; acute } \\
\text { pain; raised CA } 125\end{array}$ & $3 / 4$ & & 178 \\
\hline \multicolumn{8}{|l|}{ Malignant tumours } \\
\hline \multicolumn{8}{|l|}{ Epithelial } \\
\hline Borderline serous & $\begin{array}{c}\text { Median, } 42 \\
30 \%<40\end{array}$ & $\begin{array}{c}\text { Uni }(73 \%) / \text { bi } \\
(27 \%)\end{array}$ & $\begin{array}{c}\text { Unilocular- } \\
\text { solid }(55 \%) \text { or } \\
\text { multilocular-solid } \\
(30 \%) \text {; cystic fluid } \\
\text { anechoic }(47 \%) \text { or } \\
\text { low-level }\end{array}$ & $\begin{array}{c}>3 \text { irregular } \\
\text { papillations }(81 \%) \\
\text { with internal blood } \\
\text { flow and anechoic } \\
\text { spaces; } \\
\text { no shadowing }\end{array}$ & $2 / 3$ & & $\begin{array}{l}179 \\
180 \\
181\end{array}$ \\
\hline $\begin{array}{l}\text { Borderline } \\
\text { mucinous } \\
\text { (intestinal type) } \\
(30-50 \%)\end{array}$ & Median, 50 & Uni & $\begin{array}{c}\text { Multilocular }(80 \%) \\
\text { or unilocular } \\
(15 \%) ; \text { very large } \\
\text { tumour ( median } \\
\text { diameter, } 195 \mathrm{~mm})\end{array}$ & $\begin{array}{l}\text { Multiple small } \\
\text { loculi, often } \\
\text { 'honeycomb } \\
\text { nodule'; no } \\
\text { papillations; cystic } \\
\text { fluid low-level }\end{array}$ & $2 / 3$ & & $\begin{array}{r}176 \\
179\end{array}$ \\
\hline $\begin{array}{l}\text { Borderline } \\
\text { mucinous } \\
\text { (endocervical type) }\end{array}$ & $30-40$ & Uni & $\begin{array}{l}\text { Unilocular-solid; } \\
\text { sometimes } \\
\text { multilocular-solid; } \\
\text { median diameter, } \\
37 \mathrm{~mm}\end{array}$ & $\begin{array}{c}\text { Papillations }(60 \%) ; \\
\text { cystic fluid } \\
\text { low-level or } \\
\text { ground-glass }\end{array}$ & $2 / 3$ & & $\begin{array}{l}176 \\
179\end{array}$ \\
\hline
\end{tabular}


Table I. - Continued.

\begin{tabular}{|c|c|c|c|c|c|c|c|}
\hline Category/Type & Age (years) & Laterality & Appearance & Typical features & Colour score & Image & Ref \\
\hline $\begin{array}{l}\text { Borderline } \\
\text { seromucinous } \\
\text { (new category) }\end{array}$ & Median 42 & Uni & $\begin{array}{l}\text { Contain } \\
\text { endometrioid-, } \\
\text { indifferent- and } \\
\text { squamous-type } \\
\text { epithelium }\end{array}$ & $\begin{array}{l}\text { Frequently } \\
\text { associated with } \\
\text { endometriosis }\end{array}$ & - & - & $\begin{array}{l}176, \\
179\end{array}$ \\
\hline $\begin{array}{l}\text { Low-grade serous } \\
\text { carcinoma }\end{array}$ & Median, 53 & $\operatorname{Bi}(60 \%)$ & $\begin{array}{l}\text { Multilocular-solid } \\
\text { (55\%) or solid } \\
(32 \%)\end{array}$ & $\begin{array}{l}\text { Small calcifications } \\
\text { in solid tissue; } \\
\text { papillations }(32 \%)\end{array}$ & $2 / 3 / 4$ & & 180 \\
\hline $\begin{array}{l}\text { High-grade serous } \\
\text { carcinoma }\end{array}$ & $55-65$ & $\mathrm{Bi}(50 \%)$ & $\begin{array}{l}\text { Solid (64\%) or } \\
\text { multilocular-solid } \\
(33 \%)\end{array}$ & $\begin{array}{l}\text { Areas of necrosis in } \\
\text { solid tissue; rarely, } \\
\text { papillations }(7 \%)\end{array}$ & $2 / 3 / 4$ & & 180 \\
\hline $\begin{array}{l}\text { Mucinous } \\
\text { carcinoma (3\%) }\end{array}$ & Median, 53 & Uni $(80 \%)$ & $\begin{array}{l}\text { Multilocular-solid } \\
(55 \%) \text {, multilocular } \\
\text { or solid }\end{array}$ & $\begin{array}{c}\text { Very large tumour } \\
\text { (median diameter, } \\
197 \mathrm{~mm} \text { ); cystic } \\
\text { fluid low-level }\end{array}$ & $2 / 3 /(4)$ & & 176 \\
\hline $\begin{array}{l}\text { Endometrioid } \\
\text { carcinoma } \\
(10-15 \%)\end{array}$ & Median, 55 & $\begin{array}{l}\text { Uni }(79 \%) \text {; } \\
\text { coexist with } \\
\text { endometrial } \\
\text { carcinoma } \\
(20 \%)\end{array}$ & $\begin{array}{l}\text { Multilocular- } \\
\text { solid (48\%) with } \\
\text { low-level }(53 \%) \\
\text { or ground-glass } \\
(16 \%) \text { cystic fluid, } \\
\text { or solid ( } 34 \%) ; \\
\text { median diameter, } \\
102 \mathrm{~mm}\end{array}$ & $\begin{array}{l}\text { Cockade-like } \\
\text { appearance; } \\
\text { papillations in } 29 \% \text {; } \\
20 \% \text { develop from } \\
\text { endometriosis }\end{array}$ & $(2) / 3 / 4$ & & 183 \\
\hline $\begin{array}{l}\text { Clear-cell } \\
\text { carcinoma }(5-25 \%)\end{array}$ & Median, 55 & Uni (85\%) & $\begin{array}{c}\text { Multilocular- } \\
\text { solid (41\%), or } \\
\text { unilocular-solid } \\
(35 \%) \text { with low- } \\
\text { level }(44 \%) \text { or } \\
\text { ground-glass } \\
\text { (22\%) cystic fluid, } \\
\text { or solid }(24 \%) \text {; } \\
\text { median diameter, } \\
117 \mathrm{~mm}\end{array}$ & $\begin{array}{l}\text { Solid nodules; } \\
\text { papillations in } 38 \% \text {; } \\
20-30 \% \text { develop } \\
\text { from endometriosis }\end{array}$ & $(2) / 3 / 4$ & & 184 \\
\hline Carcinosarcoma & $\begin{array}{c}\text { Median, } 66 \\
\text { (range, 33-91) }\end{array}$ & $\mathrm{Bi}(50 \%)$ & $\begin{array}{l}\text { Solid (72.5\%); } \\
\text { multilocular-solid } \\
(24.5 \%) ; \text { median } \\
\text { diameter, } 100 \mathrm{~mm}\end{array}$ & $\begin{array}{c}\text { Most tumours } \\
\text { solid with irregular } \\
\text { margins and cystic } \\
\text { areas }\end{array}$ & $3 / 4$ & & $\S$ \\
\hline \multicolumn{8}{|c|}{ Sex cord-stromal tumour } \\
\hline $\begin{array}{l}\text { Granulosa-cell } \\
\text { tumour }(70 \%)\end{array}$ & $\begin{array}{c}50 \% \\
\text { premenopause; } \\
3-10 \% \\
\text { prepubertal } \\
\text { (juvenile type) }\end{array}$ & Uni & $\begin{array}{c}\text { Large multilocular- } \\
\text { solid/solid (median } \\
\text { diameter, } 100 \mathrm{~mm}) ; \\
\text { heterogeneous } \\
\text { solid tissue with } \\
\text { areas of necrosis } \\
\text { and haemorrhage; } \\
\text { echogenicity of } \\
\text { fluid mixed or } \\
\text { low-level; rarely, } \\
\text { papillations }\end{array}$ & $\begin{array}{c}\text { 'Swiss cheese' } \\
\text { pattern; } \\
\text { hyperoestrogenic } \\
\text { (abnormal } \\
\text { bleeding, thick } \\
\text { endometrium); } \\
\text { CA } 125 \text { normal; } \\
\text { oestradiol elevated } \\
\text { in postmenopause }\end{array}$ & $3 / 4$ & & 185 \\
\hline
\end{tabular}


Table I. - Continued.

\begin{tabular}{|c|c|c|c|c|c|c|c|}
\hline Category/Type & Age (years) & Laterality & Appearance & Typical features & Colour score & Image & Ref \\
\hline $\begin{array}{l}\text { Sertoli-Leydig-cell } \\
\text { tumour }\end{array}$ & $\leq 30(75 \%)$ & Uni (100\%) & $\begin{array}{l}\text { Large multilocular- } \\
\text { solid or solid } \\
\text { (median diameter, } \\
50-150 \mathrm{~mm} \text { ) }\end{array}$ & $\begin{array}{c}\text { Endocrine } \\
\text { symptoms } \\
\text { (one third } \\
\text { virilisation); } \\
\text { testosterone/ } \\
\text { androstenedione }\end{array}$ & $3 / 4$ & & 173 \\
\hline \multicolumn{8}{|l|}{ Germ-cell tumour } \\
\hline Dysgerminoma & $\begin{array}{l}\text { Median, 20 } \\
\text { (range, 16-31) }\end{array}$ & Uni & $\begin{array}{c}\text { Highly } \\
\text { vascularized, purely } \\
\text { solid tumours with } \\
\text { heterogeneous } \\
\text { internal } \\
\text { echogenicity } \\
\text { divided into several } \\
\text { lobules; smooth } \\
\text { and sometimes } \\
\text { lobulated contour; } \\
\text { well-defined } \\
\text { relative to } \\
\text { surrounding organs }\end{array}$ & $\begin{array}{c}\text { Internal lobular } \\
\text { appearance; raised } \\
\text { LDH, sometimes } \\
\text { AFP }\end{array}$ & $3 / 4$ & & 186 \\
\hline Yolk-sac tumour & $20-30$ & Uni & $\begin{array}{c}\text { Large and irregular } \\
\text { multilocular-solid/ } \\
\text { solid } \\
(100-200 \mathrm{~mm})\end{array}$ & $\begin{array}{c}\text { Fine-textured } \\
\text { slightly hyperechoic } \\
\text { solid tissue; raised } \\
\text { AFP }\end{array}$ & $3 / 4$ & & $\begin{array}{l}187, \\
188\end{array}$ \\
\hline Immature teratoma & $15-30$ & Uni & $\begin{array}{c}\text { Large, } \\
\text { predominantly } \\
\text { solid }\end{array}$ & $\begin{array}{c}\text { Very } \\
\text { inhomogeneous } \\
\text { solid tissue with } \\
\text { hyper-reflective } \\
\text { areas; raised AFP }\end{array}$ & $2 / 3 / 4$ & & ब \\
\hline $\begin{array}{l}\text { Endodermal-sinus } \\
\text { tumour* }\end{array}$ & - & - & - & Always raised AFP & - & - & - \\
\hline Choriocarcinoma & Median, 36 & Uni & $\begin{array}{l}\text { Large, solid } \\
\text { (inhomogeneous } \\
\text { echogenicity) with } \\
\text { small and irregular } \\
\text { cystic spaces }\end{array}$ & Raised hCG & $(3) / 4$ & & 189 \\
\hline $\begin{array}{l}\text { Embryonal } \\
\text { carcinoma }\end{array}$ & $14-20$ & Uni & $\begin{array}{c}\text { Large, solid } \\
\text { (inhomogeneous } \\
\text { echogenicity) with } \\
\text { small and irregular } \\
\text { cystic spaces }\end{array}$ & $\begin{array}{c}\text { Raised } \mathrm{hCG} \text { and } \\
\text { AFP }\end{array}$ & $(3) / 4$ & & 189 \\
\hline $\begin{array}{l}\text { Malignant mixed } \\
\text { germ-cell tumour }\end{array}$ & Median, 18 & Uni & $\begin{array}{c}\text { Large, solid } \\
\text { (inhomogeneous } \\
\text { echogenicity) with } \\
\text { small and irregular } \\
\text { cystic spaces }\end{array}$ & $\begin{array}{c}\text { Raised hCG/LDH/ } \\
\text { AFP }\end{array}$ & $(3) / 4$ & & 189 \\
\hline
\end{tabular}




\begin{tabular}{|c|c|c|c|c|c|c|c|}
\hline Category/Type & Age (years) & Laterality & Appearance & Typical features & Colour score & Image & Ref \\
\hline \multicolumn{8}{|c|}{ Secondary metastatic } \\
\hline $\begin{array}{l}\text { Breast, stomach, } \\
\text { lymphoma or } \\
\text { uterus }\end{array}$ & Median, 56 & $\begin{array}{c}\operatorname{Bi}(50-75 \%) / \\
\text { uni }\end{array}$ & $\begin{array}{c}\text { Solid (median } \\
\text { diameter, } 70 \mathrm{~mm} \text { ) }\end{array}$ & $\begin{array}{l}\text { 'Lead-vessel' sign; } \\
\text { CA } 125 \text { moderately } \\
\text { raised in } 75 \% \text {; } \\
\text { CA } 15-3 \text { raised } \\
\quad \text { (breast) }\end{array}$ & $3 / 4$ & & 190 \\
\hline $\begin{array}{l}\text { Colon, rectum, } \\
\text { appendix } \\
\text { or biliary tract }\end{array}$ & $\begin{array}{c}\text { Median, 56; } \\
\text { appendix } \\
\text { younger (25-50) }\end{array}$ & $\begin{array}{c}\mathrm{Bi}(50-75 \%) / \\
\text { uni }\end{array}$ & $\begin{array}{c}\text { Multilocular/ } \\
\text { multilocular-solid } \\
\text { (median diameter, } \\
120 \mathrm{~mm} \text { ); many } \\
\text { locules; } \\
\text { irregular; } \\
\text { papillations }\end{array}$ & $\begin{array}{l}\text { CA } 125 \text { moderately } \\
\text { raised in } 75 \% \\
\text { CEA raised (colon, } \\
\text { rectum)/CA19-9 } \\
\text { raised (biliary tract) }\end{array}$ & $(2) / 3 /(4)$ & & 190 \\
\hline \multicolumn{8}{|c|}{ Tumour of Fallopian tube: epithelial } \\
\hline Tubal cancer & $55-60$ & Uni $(90 \%)$ & $\begin{array}{c}\text { Completely solid } \\
\text { or with large solid } \\
\text { component(s) and } \\
\text { anechoic cystic } \\
\text { fluid; average, } \\
50 \mathrm{~mm}\end{array}$ & $\begin{array}{l}\text { Well-vascularized } \\
\text { ovoid or sausage- } \\
\text { shaped structure; } \\
\text { normal ovarian } \\
\text { tissue adjacent in } \\
50 \%\end{array}$ & $3 / 4$ & & 191 \\
\hline \multicolumn{8}{|c|}{$\begin{array}{l}\text { All example images in this table are reproduced from the cited references in Ultrasound in Obstetrics and Gynaecology. } \\
\text { *Yolk-sac tumour. †Heremans et al. (pers. comm.). }+ \text { Virgilio et al. (pers. comm.). §Ciccarone et al. (pers. comm.). } \\
\text { I Landolfo et al. (pers. comm.). AFP, alpha-fetoprotein; Bi, bilateral; hCG, human chorionic gonadotrophin; LDH, } \\
\text { lactate dehydrogenase; Ref, reference; Uni, unilateral. }\end{array}$} \\
\hline
\end{tabular}

RMI in classifying adnexal masses (Akturk et al., 2011; Al-Musalhi et al., 2015; Al Musalhi et al., 2016; Anton et al., 2012; Bouzari et al., 2011; Chacon et al., 2019; Chopra et al., 2015; Dochez et al., 2019; Hada et al., 2020; Javdekar \& Maitra, 2015; Khoiwal et al., 2019; Meys et al., 2016; Westwood et al., 2018; Zhang et al., 2019). Three variants of the RMI (RMI-II, RMI-III, RMI-IV) have been developed, but these offer no significant additional diagnostic advantage compared with the original version (RMI-I) (Akturk et al., 2011; Hada et al., 2020; Meys et al., 2016; Zhang et al., 2019). Moore et al. (2008) developed an algorithm, the risk of ovarian malignancy algorithm (ROMA), based on both CA 125 and human epididymis protein 4 (HE4). Westwood et al. (2018) pooled data comparing the ROMA with the RMI-I to guide referral decisions for women with suspected ovarian cancer and found similar performance if women with borderline tumours and non-epithelial cancers were excluded from the analyses. More recently, another meta-analysis showed a higher specificity of the RMI-I than the ROMA in premenopausal women but a similar performance for detecting ovarian cancer in postmenopausal women presenting with an adnexal mass (Chacon et al., 2019). Limitations of the RMI are the absence of an estimated risk of malignancy, and its considerable dependence on serum CA 125, the latter resulting in a relatively low sensitivity for early-stage invasive and borderline disease, especially in premenopausal women (Kaijser et al., 2013; Timmerman et al., 2007) (see Tumour Markers).

\section{IOTA methods}

To homogenize and standardize the quality, description and evaluation of ultrasonography across different centres, and thereby increase diagnostic accuracy, the IOTA group first published a consensus paper on terms and definitions to describe adnexal lesions in 20003 (Timmerman et al., 2016). Using this standardized methodology, the IOTA group has developed different prediction models based on logistic regression analysis (Timmerman et al., 2005; Timmerman et al., 2016; Van Calster et al., 2014). In a large-scale external validation study, Van Holsbeke et al. (2012) showed that the IOTA logistic regression models 1 (LR1, with 12 variables) and 2 (LR2, with six variables) outperformed 12 other models, including the RMI. The LR2 model was easier to use than the LR1 
model. Demonstrating the standardization and reproducibility of the IOTA models, Sayasneh et al. (2013) showed that even less-experienced sonographers are able to differentiate accurately between benign and malignant ovarian masses using the IOTA LR1 model. The IOTA group also developed 'Simple Rules' that may be applied to a mass based on the presence or absence of five benign and five malignant ultrasound features. These rules can be applied to about $80 \%$ of adnexal masses, with the rest being classed as inconclusive. They have now been broadly accepted and are widely used in clinical practice (Alcazar et al., 2013; Hartman et al., 2012; Knafel et al., 2016; Nunes et al., 2014; Ruiz de Gauna et al., 2015; Sayasneh et al., 2013; Tantipalakorn et al., 2014; Timmerman et al., 2010; Timmerman et al., 2008). More recently, a logistic regression model based on the ultrasound features of the original Simple Rules was developed, i.e. the Simple Rules risk model. This model is able to provide an individual estimated risk of malignancy for any type of lesion (Timmerman et al., 2016). A summary of the main models and scoring systems for the preoperative diagnosis of ovarian tumours is presented in Table II.

As many ovarian masses can be recognized relatively easily, the IOTA group also proposed four 'Simple Descriptors' of the features typical of common benign lesions and two suggestive of malignancy, which can give an 'instant diagnosis' and reflect the pattern recognition that is a key part of ultrasonography. These are applicable to about $43 \%$ of adnexal masses (Ameye et al., 2012). A three-step strategy, consisting of the sequential use of Simple Descriptors, Simple Rules and subjective assessment by an expert, had high accuracy for discriminating between benign and malignant adnexal lesions (Ameye et al., 2012). A systematic review and meta-analysis reported better performance of the IOTA Simple Rules and the IOTA LR2 model compared with all other scoring systems, including the RMI (Kaijser et al., 2014). Besides confirming these findings, another meta-analysis highlighted that a two-step approach, with the IOTA Simple Rules as the first step and subjective assessment by an expert for inconclusive tumours as the second step, matched the test performance of expert ultrasound examiners (Meys et al., 2016). The IOTA Simple Rules have been integrated into several national clinical guidelines for the evaluation and management of adnexal masses (American College of Obstetricians and Gynecologists' Committee on Practice Bulletins, 2016) and they were considered the main diagnostic strategy (Glanc et al., 2017) as part of a first international consensus report for the assessment of adnexal masses.
A randomized controlled trial assessing surgical intervention rates and the oncologic safety of decision-making processes using on an RMI-based protocol developed by the British Royal College of Obstetricians and Gynaecologists (RCOG) vs triage using the IOTA Simple Rules (Nunes et al., 2017) showed that the IOTA protocol resulted in lower surgical intervention rates compared with the RMI-based RCOG protocol. The IOTA Simple Rules did not result in more cases in which a diagnosis of cancer was delayed. It was found that the addition of biomarkers such as serum CA 125 and HE4 when using the IOTA Simple Rules, with or without subjective assessment by an expert sonographer, offered no additional diagnostic advantage for the characterization of ovarian masses, but was more costly than a threestep strategy based on the sequential use of the IOTA Simple Descriptors, Simple Rules and expert evaluation (Alcazar et al., 2016; Piovano et al., 2017).

The IOTA group have also developed the Assessment of Different NEoplasias in the adneXa (ADNEX) model. This multiclass prediction model is the first risk model to differentiate between benign and malignant tumours, whilst also offering subclassification of any malignancy into borderline tumours, Stage-I and Stage-IIIV primary cancers and secondary metastatic tumours. The IOTA ADNEX model was developed and validated using parameters collected by experienced ultrasound examiners (Van Calster et al., 2014). Several external validation studies have shown good to excellent performance of the ADNEX model in discriminating different types of ovarian tumour, with a higher clinical value than the RMI (Araujo et al., 2017; Meys et al., 2017; Sayasneh et al., 2016; Szubert et al., 2016; Van Calster, 2017; Van Calster et al., 2016; Wynants et al., 2017). A study aiming to validate the ADNEX model when applied by Level-II examiners has confirmed that it can be used successfully by less-experienced examiners (Viora et al., 2020). A large multicentre cohort study of 4905 masses in 17 centres, comparing six different prediction models (RMI, LR2, Simple Rules, Simple Rules risk model and ADNEX model with or without CA 125), demonstrated the IOTA ADNEX model and the IOTA Simple Rules risk model to be the best models for the characterization of ovarian masses in patients who present with an adnexal lesion (Van Calster et al., 2020).

\section{GI-RADS}

The Gynaecologic Imaging Reporting and Data System (GI-RADS) was first introduced by Amor 
Table II. - Continued.

\begin{tabular}{|c|c|c|}
\hline Model or system: type & Predictor variables & Remarks \\
\hline $\begin{array}{l}\text { Simple descriptors : classifica- } \\
\text { tion as benign or malignant }\end{array}$ & $\begin{array}{l}\text { Benign descriptor (BD) 1: Unilocular tumour with } \\
\text { ground-glass echogenicity in a premenopausal woman; } \\
\text { BD2: Unilocular tumour with mixed echogenicity and } \\
\text { acoustic shadows in a premenopausal woman; } \\
\text { BD3 Unilocular anechoic tumour with regular walls and } \\
\text { maximum diameter of lesion }<10 \mathrm{~cm} \text {; } \\
\text { BD4 Remaining unilocular tumour with regular walls; } \\
\text { Malignant descriptor (MD) 1: Tumour with ascites and at } \\
\text { least moderate colour Doppler blood flow in a postmeno- } \\
\text { pausal woman; } \\
\text { MD2 Age }>50 \text { years and CA } 125>100 \mathrm{U} / \mathrm{mL}\end{array}$ & $\begin{array}{l}\text { No risk estimates } \\
\text { Based on clinical, ultrasound and CA } 125 \\
\text { information } \\
\text { Possible to calculate result without computer }\end{array}$ \\
\hline RMI : score & $\begin{array}{l}\text { CA 125, menopausal status, ultrasound score based on } \\
\text { five binary ultrasound variables (multilocular cyst, solid } \\
\text { areas, bilateral lesions, ascites, evidence of metastases on } \\
\text { abdominal ultrasound) }\end{array}$ & $\begin{array}{l}\text { No risk estimates } \\
\text { Based on clinical, ultrasound and CA } 125 \\
\text { information } \\
\text { Possible to calculate result without computer } \\
\text { Online calculators available }\end{array}$ \\
\hline $\begin{array}{l}\text { Simple Rules : classification } \\
\text { as benign, inconclusive or } \\
\text { malignant }\end{array}$ & $\begin{array}{l}\text { Classification based on } 10 \text { binary features, i.e. five benign } \\
\text { and five malignant features: } \\
\text { Benign features: unilocular cyst, smooth multilocular } \\
\text { cyst with largest diameter }<100 \mathrm{~mm} \text {, presence of solid } \\
\text { areas with largest diameter }<7 \mathrm{~mm} \text {, acoustic shadows, no } \\
\text { vascularization on colour Doppler } \\
\text { Malignant features: irregular solid tumour, irregular } \\
\text { multilocular solid tumour with largest diameter } \geq 100 \mathrm{~mm} \text {, } \\
\text { presence of ascites, } \geq 4 \text { papillary projections, very strong } \\
\text { vascularization on colour Doppler }\end{array}$ & $\begin{array}{l}\text { No risk estimates } \\
\text { Classification into only three groups } \\
\text { Based on dichotomized ultrasound features } \\
\text { Easy to use without computer } \\
\text { Available as smartphone app }\end{array}$ \\
\hline $\begin{array}{l}\text { LR2: } \\
\text { risk model based on logistic } \\
\text { regression }\end{array}$ & $\begin{array}{l}\text { Age (years), presence of acoustic shadows, presence of } \\
\text { ascites, presence of papillary projections with blood flow, } \\
\text { maximum diameter of largest solid component, irregular } \\
\text { internal cyst walls }\end{array}$ & $\begin{array}{l}\text { Risk estimates } \\
\text { Based on clinical and ultrasound information } \\
\text { Requires computer } \\
\text { Available as smartphone app }\end{array}$ \\
\hline $\begin{array}{l}\text { Simple Rules risk: risk model } \\
\text { based on logistic regression }\end{array}$ & $\begin{array}{l}\text { The } 10 \text { binary features used in the Simple Rules, type of } \\
\text { centre (oncology centre } v s \text { other) }\end{array}$ & $\begin{array}{l}\text { Risk estimates } \\
\text { Based on dichotomized ultrasound features } \\
\text { Developed to add risk estimates for Simple Rules } \\
\text { Available as online calculator; available in } \\
\text { ultrasound machines from some manufacturers }\end{array}$ \\
\hline $\begin{array}{l}\text { ADNEX } \\
\text { without CA } 125: \\
\text { risk model based on } \\
\text { multinomial logistic } \\
\text { regression }\end{array}$ & $\begin{array}{l}\text { Age (years), maximum diameter of lesion (mm), maximum } \\
\text { diameter of largest solid component (mm), number of } \\
\text { papillary projections (ordinal), presence of acoustic } \\
\text { shadows, presence of ascites, presence of more than } 10 \\
\text { cyst locules, type of centre (oncology centre } v s \text { other) }\end{array}$ & $\begin{array}{l}\text { Risk estimates } \\
\text { Also estimates risk of four subtypes of malignancy } \\
\text { Based on clinical and ultrasound information } \\
\text { Subjective predictors are avoided a priori (e.g. } \\
\text { colour score or irregular cyst walls) } \\
\text { Requires computer } \\
\text { Available as smartphone app and as online } \\
\text { calculator; available in ultrasound machines from } \\
\text { some manufacturers }\end{array}$ \\
\hline $\begin{array}{l}\text { ADNEX } \\
\text { with CA 125: } \\
\text { risk model based on } \\
\text { multinomial logistic } \\
\text { regression }\end{array}$ & $\begin{array}{l}\text { Same variables as for ADNEX without CA } 125 \text {, and } \\
\text { additionally serum CA } 125 \text { (IU/L) }\end{array}$ & $\begin{array}{l}\text { Risk estimates } \\
\text { Also estimates risk of four subtypes of malignancy } \\
\text { Based on clinical, ultrasound and CA } 125 \\
\text { information } \\
\text { Subjective predictors are avoided a priori (e.g. } \\
\text { colour score or irregular cyst walls) } \\
\text { Requires computer } \\
\text { Available as smartphone app and as online } \\
\text { calculator; available in ultrasound machines from } \\
\text { some manufacturers }\end{array}$ \\
\hline
\end{tabular}


et al. in 2009 and was validated prospectively by the same team in a multicentre study 2 years later (Amor et al., 2011; Amor et al., 2009). This reporting system quantifies the risk of malignancy into five categories: GI-RADS 1, definitively benign (estimated probability of malignancy $(E P M)=0 \%)$; GI-RADS 2, very probably benign $($ EPM < 1\%); GI-RADS 3, probably benign $(\mathrm{EPM}=1-4 \%)$; GI-RADS 4, probably malignant $(\mathrm{EPM}=5-20 \%)$; and GI-RADS 5, very probably malignant $(E P M>20 \%)$. More recently, several studies have demonstrated the value of the GIRADS system for the assessment of malignant adnexal masses in women who are candidates for surgical intervention. Furthermore, the addition of GI-RADS to CA 125 improves the identification of adnexal masses at high risk of malignancy compared with using CA 125 alone (Basha et al., 2019; Behnamfar et al., 2019; Koneczny et al., 2017; Migda et al., 2018; Zhang et al., 2017; Zheng et al., 2019).

\section{$O-R A D S$}

The Ovarian-Adnexal Reporting and Data System (O-RADS) lexicon for ultrasound was published in 2018, providing a standardized glossary that includes all appropriate descriptors and definitions of the characteristic ultrasound appearance of normal ovaries and various adnexal lesions (Andreotti et al. 2018; 2019). The O-RADS ultrasound working group developed an adnexalmass triage system based either on the O-RADS descriptors or on the risk of malignancy assigned to the mass using the IOTA ADNEX model to classify ovarian tumours into different risk categories (Andreotti et al., 2020). However, to date, neither the triage system nor the O-RADS descriptors have been externally validated. Basha et al. (2020) determined the malignancy rates, validity and reliability of the O-RADS approach when applied to a database of 647 adnexal masses collected before the development of the O-RADS system. In this retrospective study, the O-RADS system had significantly higher sensitivity than did the GI-RADS system and the IOTA Simple Rules, with a non-significant slightly lower specificity compared with both GI-RADS and IOTA Simple Rules, and with similar reliability.

\section{Statements on ultrasonography (Statements 1-6)}

1. Subjective assessment by expert (Level-III) ultrasound examiners has the best performance to distinguish between benign and malignant ovarian tumours.

- Level of evidence: 1a

- Grade of statement: A

- Consensus: yes, $95 \%(\mathrm{n}=19)$; no, $0 \%(\mathrm{n}=0)$; abstain, $5 \%(\mathrm{n}=1)$

2. If an expert ultrasound examiner is not available, the use of ultrasound-based diagnostic models can assist clinicians to distinguish between benign and malignant ovarian tumours.

- Level of evidence: $2 \mathrm{a}$

- Grade of statement: B

- Consensus: yes, $90 \%(\mathrm{n}=18)$; no, $0 \%(\mathrm{n}=0)$; abstain, $10 \%(\mathrm{n}=2)$

3. Ultrasound-based diagnostic models (IOTA Simple Rules risk model or IOTA ADNEX model) are preferable to CA 125 level, HE4 level or ROMA as they are superior in distinguishing between benign and malignant ovarian tumours.

- Level of evidence: $2 b$

- Grade of statement: B

- Consensus: yes, $95 \%(\mathrm{n}=19)$; no, $0 \%(\mathrm{n}=0)$; abstain, $5 \%(\mathrm{n}=1)$

4. The IOTA ADNEX model and the IOTA Simple Rules risk model are recommended as they outperform existing morphological scoring systems, including the RMI.

- Level of evidence: $1 \mathrm{~b}$

- Grade of statement: A

- Consensus: yes, 95\% $(\mathrm{n}=19)$; no, $0 \%(\mathrm{n}=0)$; abstain, $5 \%(\mathrm{n}=1)$

5. The IOTA ADNEX model is a multiclass model and is helpful to differentiate between benign tumours, borderline tumours, early- or advancedstage ovarian cancer and secondary metastatic tumours.

- Level of evidence: $3 b$

- Grade of statement: C

- Consensus: yes, $85 \%(\mathrm{n}=17)$; no, $0 \%(\mathrm{n}=0)$; abstain, $15 \%(\mathrm{n}=3)$

6. The threshold risk of there being a secondary metastatic tumour (as predicted by the IOTA ADNEX model), above which additional investigations to detect the primary organ of origin should be triggered, is $10 \%$.

- $\quad$ Level of evidence: 5

- $\quad$ Grade of statement: D

- Consensus: 5\% threshold, $10 \%(\mathrm{n}=2)$; $10 \%$ threshold, $75 \%(\mathrm{n}=15) ; 15 \%$ threshold, $0 \%(\mathrm{n}=0) ; 20 \%$ threshold, $0 \%(\mathrm{n}=0)$; abstain, $15 \%(\mathrm{n}=3)$

Levels of evidence and grades are described in Table III. 
According to a systematic quantitative review assessing the accuracy of CA 125 level in the diagnosis of benign, borderline and malignant ovarian tumours, CA 125 is the best available single-protein biomarker identified to date (Medeiros et al., 2009). Although it lacks sensitivity and specificity for early stages of the disease and has a relatively low specificity overall, it can help direct treatment options in patients with suspicious ovarian masses. Pooled analyses have highlighted that a high body mass index and ethnicity might influence CA 125 levels, representing an additional diagnostic challenge (Babic et al., 2017). Other factors that influence CA 125 levels are the age of the patient, pregnancy, inflammatory processes and the presence of fibroids or endometriosis (Babic et al., 2017; Cramer et al., 2010; Johnson et al., 2008; Pauler et al., 2001).

Multiple studies, including meta-analyses, have highlighted the role of HE4 as a potential complement to CA 125 , especially in differentiating benign endometriotic and inflammatory lesions in younger women (Al Musalhi et al., 2016; Cao et al., 2018; Huang et al., 2018; Jacob et al., 2011; Jia et al., 2017; Kim et al., 2019; Kotowicz et al., 2015; Li et al., 2012; Lin et al., 2013; Lycke et al., 2018; Melo et al., 2018; Richards et al., 2015; Romagnolo et al., 2016; Sandri et al., 2013; Shin et al., 2020; Stiekema et al., 2014; Terlikowska et al., 2016; Van Gorp et al., 2012; Wang et al., 2014; $\mathrm{Xu}$ et al., 2016; Yanaranop et al., 2017; Yanaranop et al., 2018; Yu et al., 2012; Zhang et al., 2015). Additional tumour markers (as in the ROMA test) have failed to improve significantly the discrimination between benign and malignant masses compared with CA 125 alone (Chen et al., 2015; Choi et al., 2020; Cui et al., 2019; Huy et al., 2018; Kaijser, Van Gorp, et al., 2014; Kim et al., 2019; Kotowicz et al., 2015; Lycke et al., 2018; Melo et al., 2018; Piovano et al., 2017; Romagnolo et al., 2016; Sandri et al., 2013; Shen et al., 2017; Shin et al., 2020; Terlikowska et al., 2016; Xu et al., 2016; Yanaranop et al., 2018; Zhang et al., 2015). The combination of a more extended tumour marker profile, including the addition of carcinoembryonic antigen (CEA) and/ or carbohydrate antigen (CA 19-9) to CA 125, is useful mainly for differentiating between metastatic tumours from the gastrointestinal tract or pancreas and primary ovarian malignancy (Bozkurt et al., 2013; Kelly et al., 2010; Sagi-Dain et al., 2015a, 2015b).

\section{Statements on tumour markers} (Statements 7-12)

7. CA 125 is the best single-protein biomarker for the preoperative characterization of ovarian tumours. However, it is not useful as a screening test for ovarian cancer.

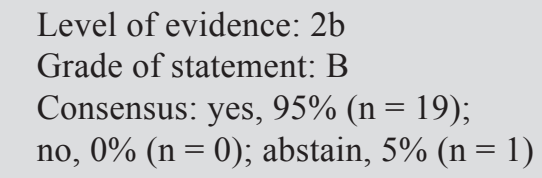

8. Neither HE4 nor ROMA improves the discrimination between benign and malignant masses compared with CA 125 alone.

- Level of evidence: $2 b$

- Grade of statement: B

- $\quad$ Consensus: yes, $70 \%(n=14)$; no, $0 \%(\mathrm{n}=0)$; abstain, 30\% $(\mathrm{n}=6)$

9. CA 125 does not increase the performance of ultrasound-based risk models to distinguish between benign and malignant tumours.

- Level of evidence: $2 b$

- Grade of statement: B

- Consensus: yes, $60 \%(n=12)$; no, $10 \%(\mathrm{n}=2)$; abstain, $30 \%(\mathrm{n}=6)$

10. CA 125 is helpful as a biomarker in cases of suspected malignancy and it helps to distinguish between subtypes of malignant tumours, such as borderline and early- and advanced-stage primary ovarian cancers and secondary metastatic tumours.

- Level of evidence: $2 b$

- Grade of statement: B

- $\quad$ Consensus: yes, $90 \%(n=18)$; no, $5 \%(\mathrm{n}=1)$; abstain, $5 \%(\mathrm{n}=1)$

11. CEA may be useful in specific cases to differentiate between primary ovarian cancer and secondary (ovarian) tumours.

Level of evidence: $3 b$

- Grade of statement: C

- $\quad$ Consensus: yes, 90\% $(\mathrm{n}=18)$; no, $0 \%(\mathrm{n}=0)$; abstain, $10 \%(\mathrm{n}=2)$

12. CA 19-9 can help to differentiate secondary metastatic tumours in the ovary.

- Level of evidence: $3 b$

- Grade of statement: C

- Consensus: yes, $75 \%(n=15)$; no, $5 \%(n=1)$; abstain, 20\% $(n=4)$

Levels of evidence and grades are described in Table III. 
Table III. - Levels of evidence and grades of statement used in this Consensus Statement.

\begin{tabular}{|c|c|c|}
\hline \multicolumn{3}{|c|}{ Levels of evidence } \\
\hline 1a & \multicolumn{2}{|c|}{$\begin{array}{l}\text { Systematic review (with homogeneity) of Level-1 diagnostic studies; or clinical decision rule with Level-1b studies } \\
\text { from different clinical centres }\end{array}$} \\
\hline $1 \mathrm{~b}$ & \multicolumn{2}{|c|}{ Validating cohort study with good reference standards; or clinical decision rule tested within one clinical centre } \\
\hline $1 \mathrm{c}$ & \multicolumn{2}{|c|}{ Absolute SpPins and SnNouts* } \\
\hline $2 \mathrm{a}$ & \multicolumn{2}{|c|}{ Systematic review (with homogeneity) of Level $>2$ diagnostic studies } \\
\hline $2 \mathrm{~b}$ & \multicolumn{2}{|c|}{$\begin{array}{l}\text { Exploratory cohort study with good reference standards; or clinical decision rule after derivation, or validated only on } \\
\text { split-sample or databases }\end{array}$} \\
\hline $3 \mathrm{a}$ & \multicolumn{2}{|c|}{ Systematic review (with homogeneity) of studies Level $\geq 3 \mathrm{~b}$} \\
\hline $3 \mathrm{~b}$ & \multicolumn{2}{|c|}{ Non-consecutive study; or without consistently applied reference standards } \\
\hline 4 & \multicolumn{2}{|c|}{ Case-control study, poor or non-independent reference standard } \\
\hline 5 & \multicolumn{2}{|c|}{ Expert opinion without explicit critical appraisal, or based on physiology, bench research or 'first principles' } \\
\hline \multicolumn{3}{|c|}{ Grades of statement } \\
\hline Code & Quality of evidence & Definition \\
\hline A & High & $\begin{array}{l}\text { Further research is very unlikely to change our confidence in the estimate of effect. } \\
\text { - Several high-quality studies with consistent results } \\
\text { - In special cases: one large, high-quality multicentre trial }\end{array}$ \\
\hline B & Moderate & $\begin{array}{l}\text { Further research is likely to have an important impact on our confidence in the estimate of } \\
\text { effect and may change the estimate. } \\
\text { - One high-quality study } \\
\text { - Several studies with some limitations }\end{array}$ \\
\hline $\mathrm{C}$ & Low & $\begin{array}{l}\text { Further research is very likely to have an important impact on our confidence in the estimate } \\
\text { of effect and is likely to change the estimate. } \\
\text { - One or more studies with severe limitations }\end{array}$ \\
\hline $\mathrm{D}$ & Very low & $\begin{array}{l}\text { Any estimate of effect is very uncertain. } \\
\text { - Expert opinion } \\
\text { - No direct research evidence } \\
\text { - One or more studies with very severe limitations }\end{array}$ \\
\hline \multicolumn{3}{|c|}{$\begin{array}{l}\text { Note: A minus sign '-' may be added to denote evidence that fails to provide a conclusive answer because it is either (a) a single result with } \\
\text { a wide confidence interval; or (b) a systematic review with considerable heterogeneity. Such evidence is inconclusive, and therefore can only } \\
\text { generate Grade D recommendations. *'Absolute SpPin' is a diagnostic finding whose specificity is so high that a positive result rules in the } \\
\text { diagnosis; 'Absolute SnNout' is a diagnostic finding whose sensitivity is so high that a negative result rules out the diagnosis. }\end{array}$} \\
\hline
\end{tabular}

Magnetic resonance imaging / computed tomography / positron emission tomographycomputed tomography

\section{Magnetic resonance imaging}

Several reports have found that magnetic resonance imaging (MRI), alone or in combination with computed tomography (CT), predicts accurately the presence of peritoneal carcinomatosis in patients undergoing preoperative evaluation for cytoreductive surgery, particularly when the assessment is carried out by an experienced radiologist (Dohan et al., 2017; Gadelhak et al., 2019; Low et al., 2015; Torkzad et al., 2015). Recently, a prospective study reported higher specificity of the IOTA LR2 model compared with subjective interpretation of MRI findings by an experienced radiologist, as well as similar sensitivities for both imaging modalities for discriminating between benign and malignant tumours (Shimada et al., 2018). The addition of diffusion-weighted techniques to conventional imaging modalities has been shown in multiple pooled studies to increase diagnostic accuracy in discriminating between benign tumours and ovarian cancer, especially in the Caucasian population, with data even suggesting a value in predicting resectability (Dai et al., 2019; Espada et al., 2013; Meng et al., 2016; Michielsen et al., 2017; Rizzo et al., 2020). However, the true extent of such a benefit needs to be validated further in multicentre, large-scale prospective randomized studies, which are currently being designed or underway (Michielsen et al., 2017). The addition of quantitative dynamic contrast-enhanced MRI to diffusion-weighted imaging and anatomical MRI sequences and the development of a 5-point scoring system (O-RADS MRI score) is another modern diagnostic development with promising potential for the differentiation between benign and malignant adnexal masses in cases in which 
ultrasound is unable to arrive at a clear diagnosis (i.e. indeterminate masses). When this technique is enhanced with volume quantification, it can help to discriminate between Type-I and Type-II epithelial ovarian cancers (Carter et al., 2013; Gity et al., 2019; He et al., 2020; Li et al., 2018; Malek et al., 2019; Thomassin-Naggara et al., 2012; Thomassin-Naggara et al., 2020). However, there are only limited data available on the impact of these modern MRI techniques on clinical decisionmaking and further studies are needed, with larger sample populations (Dirrichs et al., 2020).

\section{Computed tomography}

Dedicated multidetector CT protocols with standardized peritoneal carcinomatosis index forms are the most common diagnostic tool used in routine clinical practice to assess the extent of tumour dissemination and the presence of peritoneal carcinomatosis (Ahmed et al., 2019; Byrom et al., 2002; Esquivel et al., 2010; Marin et al., 2010; Nasser et al., 2016). A radiological peritoneal carcinomatosis index applied at preoperative CT within an expert setting has been shown to have low performance scores as a triage test to identify patients who are likely to have complete cytoreduction to no macroscopic residual disease (Avesani et al., 2020). On retrospective analysis, preoperative $\mathrm{CT}$ imaging showed high specificity but rather low sensitivity in detecting tumour involvement at key sites in ovarian cancer surgery (Nasser et al., 2016). Multiple studies that have attempted to cross-validate the accuracy of CT scans in predicting unresectable disease and incomplete cytoreduction have shown a substantial drop in accuracy rates when attempts have been made to validate them in other cohorts (Axtell et al., 2007; Bristow et al., 2000; Dowdy et al., 2004; Gemer et al., 2009; Kim et al., 2014; Nelson et al., 1993; Rutten et al., 2015; Shim et al., 2015). Thus, CT should not be used as the sole tool to predict the resectability of peritoneal carcinomatosis and exclude patients from surgery; rather, the full clinical context should be taken into account. Its widespread availability makes CT useful as a firstline diagnostic tool to identify patients who should not be selected for cytoreductive surgery, such as those with large/multifocal intraparenchymatous distant metastases, acute thromboembolic events or secondary metastatic tumours that limit the prognosis. The role of radiomics as an additional quantitative mathematical segmentation of conventional preoperative $\mathrm{CT}$ images has shown some promising results in preliminary studies; however, larger studies are necessary for validation before this technique is implemented in clinical practice (Lu et al., 2019).

\section{Positron emission tomography-computed tomography}

Positron emission tomography-computed tomography (PET-CT) may be useful in differentiating malignant from borderline or benign ovarian tumours, with the limitation that its diagnostic performance can be impacted negatively by certain tumour histological subtypes, due to the lower fluorodeoxyglucose uptake in clear-cell and mucinous invasive subtypes (Castellucci et al., 2007; Kitajima et al., 2011; Nam et al., 2010; Risum et al., 2007; Tanizaki et al., 2014; Yamamoto et al., 2008). PET-CT can also play a role as an additional technique in the diagnosis of lymphnode metastases, especially outside the abdominal cavity, or in characterizing unclear lesions in key areas that would alter clinical management, for example chest lesions (Dauwen et al., 2013; Kim \& Lee, 2018; Laghi et al., 2017). However, PET-CT does not seem to be a relevant additional diagnostic modality for the true extent of peritoneal spread of ovarian cancer, specifically bowel and mesenteric serosa, and therefore fails to predict resectability in those key sites, especially in the presence of low-volume disease (Michielsen et al., 2014). Furthermore, PET-CT has been shown to have a low diagnostic value in differentiating borderline from benign tumours and should therefore not be used in clinical decision-making processes in that context, especially when considering fertilitysparing procedures (Kitajima et al., 2011; Tanizaki et al., 2014; Yamamoto et al., 2008).

\section{Statements on MRI, CT and PET-CT (Statements 13-17)}

13. MRI with the inclusion of the functional sequences, dynamic contrast-enhanced and diffusion-weighted MRI, is not a first-line tool but may be used as a second-line tool after ultrasonography to further differentiate between benign, malignant and borderline masses.
Level of evidence: $2 \mathrm{a}$
Grade of statement: B
Consensus: yes, $100 \%(n=20)$; no, $0 \%(\mathrm{n}=0)$; abstain, $0 \%(\mathrm{n}=0)$

14. PET-CT and whole-body diffusion MRI as a second step can help to detect non-ovarian origin of secondary metastatic tumours if suspicions are raised by the initial ultrasound examination.

Level of evidence: 4

Grade of statement: C

Consensus: yes, $90 \%(\mathrm{n}=18)$; no, $0 \%(\mathrm{n}=0)$; abstain, $10 \%(\mathrm{n}=2)$ 
15. PET-CT cannot differentiate reliably between borderline and benign tumours.

Level of evidence: 4

Grade of statement: C

Consensus: yes, 95\% $(\mathrm{n}=19)$;

no, $0 \%(\mathrm{n}=0)$; abstain, $5 \%(\mathrm{n}=1)$

16. Imaging alone cannot detect reliably the entire extent of either peritoneal carcinomatosis (especially in cases of small-volume carcinomatosis) or mesenteric and bowel serosal involvement.

Level of evidence: $3 b$

Grade of statement: B

Consensus: yes, $85 \%(\mathrm{n}=17)$;

no, $5 \%(\mathrm{n}=1)$; abstain, $10 \%(\mathrm{n}=2)$

17. Imaging alone should not be used for surgical decision-making in terms of the prediction of peritoneal tumour resectability.

Level of evidence: $3 b$

Grade of statement: B

Consensus: yes, $80 \%(\mathrm{n}=16)$;

no, $15 \%(\mathrm{n}=3)$; abstain, $5 \%(\mathrm{n}=1)$

Levels of evidence and grades are described in Table III.

\section{Circulating cell-free DNA and circulating tumour cells}

Circulating cell-free DNA and circulating tumour cells as non-invasive cancer biomarkers and in non-invasive biopsy (sometimes called 'liquid biopsy') have been investigated in multiple studies (Barbosa et al., 2018; Chen et al., 2019; Giannopoulou et al., 2018; Guo et al., 2018; Kolostova et al., 2015; B. Li et al., 2019; N. Li et al., 2019; Lou et al., 2018; Phallen et al., 2017; Suh et al., 2017; Vanderstichele et al., 2017; Widschwendter et al., 2017; Yu et al., 2019; Zhou et al., 2016). DNA methylation patterns in cellfree DNA show potential to detect a proportion of ovarian cancers up to 2 years in advance of diagnosis. They may potentially guide personalized treatment, even though validation studies are lacking. The prospective use of novel collection vials, which stabilize blood cells and reduce background DNA contamination in serum/plasma samples, will facilitate the clinical implementation of liquid biopsy analyses (Widschwendter et al., 2017). A prospective evaluation of the potential of cell-free DNA for the diagnosis of primary ovarian cancer using chromosomal instability as a read-out suggested that this might be a promising method to increase the specificity of the presurgical prediction of malignancy in patients with adnexal masses (Vanderstichele et al., 2017). However, even though these circulating biomarkers play a key role in understanding metastasis and tumorigenesis and provide comprehensive insight into tumour evolution and dynamics during treatment and disease progression, they still have not been established as part of routine clinical practice (Barbosa et al., 2018; Chen et al., 2019; Giannopoulou et al., 2018).

One meta-analysis suggested that quantitative analysis of cell-free DNA has unsatisfactory sensitivity but acceptable specificity for the diagnosis of ovarian cancer (Zhou et al., 2016). In a more recent meta-analysis, cell-free DNA appeared to be slightly better than CA 125 and similar to HE4 with respect to its diagnostic ability to discriminate individuals with from those without ovarian cancer (Li et al., 2019). Nevertheless, the diagnostic value of cell-free DNA in ovarian cancer patients remains unclear and the data should be interpreted with caution. Further large-scale prospective studies are strongly recommended to validate the potential applicability of using circulating cell-free DNA, alone or in combination with conventional markers, as a diagnostic biomarker for ovarian cancer, and to explore potential factors that may influence the accuracy of ovarian cancer diagnosis (Zhou et al., 2016).

\section{Statement on circulating cell-free DNA and tumour cells (Statement 18)}

18. Circulating cell-free DNA and circulating tumour cells should not yet be used in routine clinical practice to differentiate between benign and malignant ovarian masses.

Level of evidence: 4

- Grade of statement: C

- $\quad$ Consensus: yes, $85 \%(n=17)$; no, $5 \%(\mathrm{n}=1)$; abstain, $10 \%(\mathrm{n}=2)$

Levels of evidence and grades are described in Table III.

\section{Overview of consensus}

The experts also reached a consensus on a flowchart describing steps recommended to distinguish between benign and malignant tumours (Figure 2) and to direct patients towards appropriate treatment pathways. Ultrasonography is recommended as a first step to stratify patients with symptoms suggestive of an adnexal mass, and in those with an incidental finding of an adnexal mass on imaging. If the scan rules out normal ovaries and physiological changes (i.e. rules out O-RADS 1), the IOTA ADNEX model could be applied as a next step in order to determine the risk 


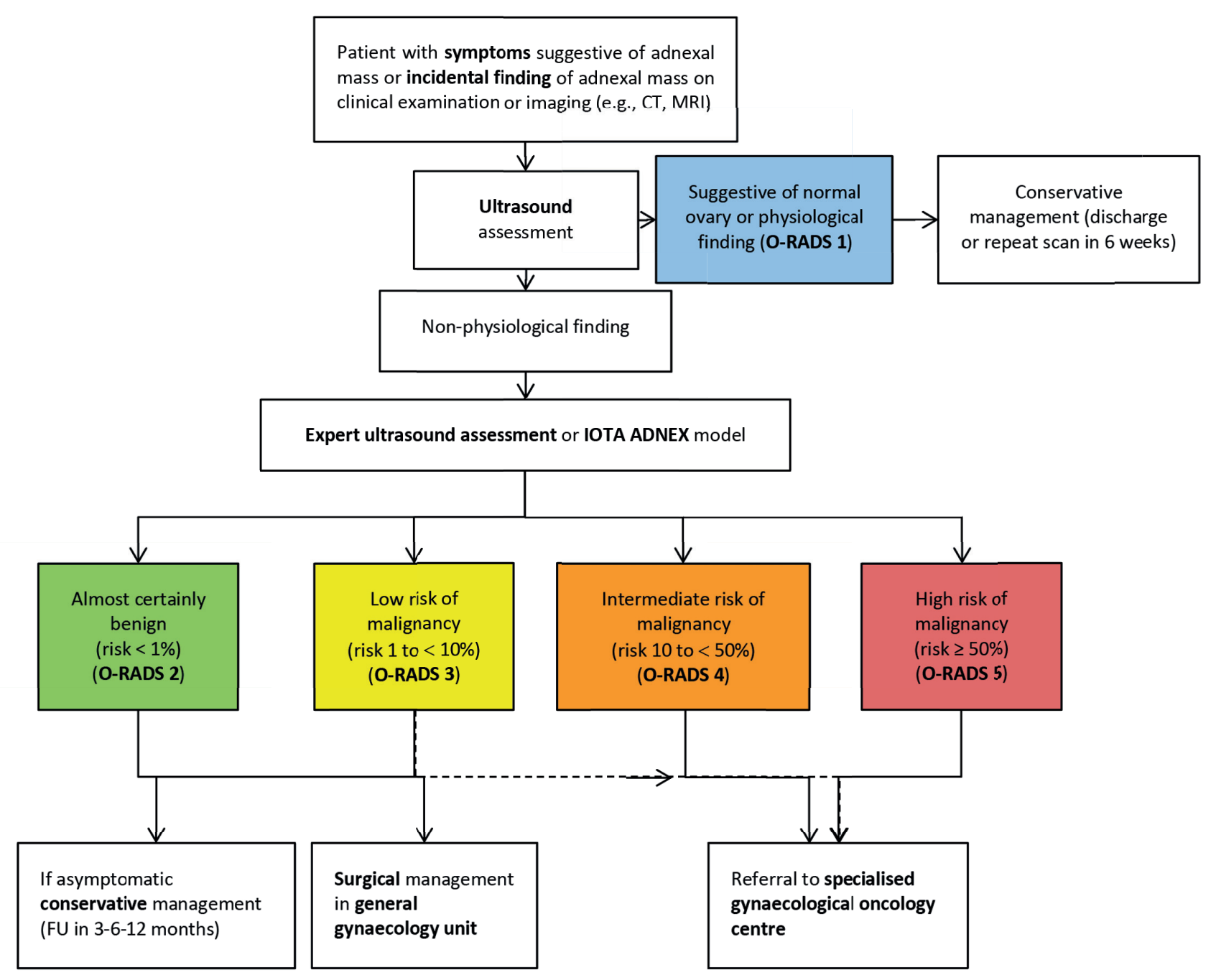

Figure 2: Flowchart of steps recommended to distinguish between benign and malignant tumours and to direct patients towards appropriate treatment pathway. CT, computed tomography; F/U, follow-up; IOTA ADNEX, International Ovarian Tumour Analysis Group Assessment of Different NEoplasias in the adneXa; MRI, magnetic resonance imaging; O-RADS, Ovarian-Adnexal Reporting and Data System.

of malignancy. Any ultrasonographic examination in the case of a suspected ovarian mass should be performed by an expert sonographer. The resulting classification of the lesion into one of the O-RADS categories (2-5) can further guide the management and selection of patients for referral to a dedicated gynaecological oncology centre.

A consensus was also reached on further steps necessary to differentiate between subgroups of malignancy and extent of disease within gynaecological oncology centres (Figure 3). Ultrasound assessment by an expert or application of the IOTA ADNEX model in combination with the tumour marker profile (CA 125 and CEA, complemented with other markers in specific cases) can often indicate the specific subtype of malignancy. If available, diagnosis of the primary lesion can be confirmed with diffusionand perfusion-weighted MRI, especially in cases in which fertility-sparing surgery is considered. A CT scan of chest, abdomen and pelvis is mandatory before planned surgery for presumed malignancy, in order to exclude secondary cancers, thromboembolic events, and multifocal intraparenchymal distant metastases that would preclude operability. The final management and treatment journey of the patient should be determined within an expert multidisciplinary setting, taking into account both the diagnostic findings and the overall patient profile, including symptoms, patient preferences and prior surgical, medical and reproductive history, with the ultimate aim of defining an individualized approach for every patient.

Correspondence at: Dirk Timmerman, UZ Herestraat 49 box 7003,3000 Leuven, dirk.timmerman@uzleuven.be 


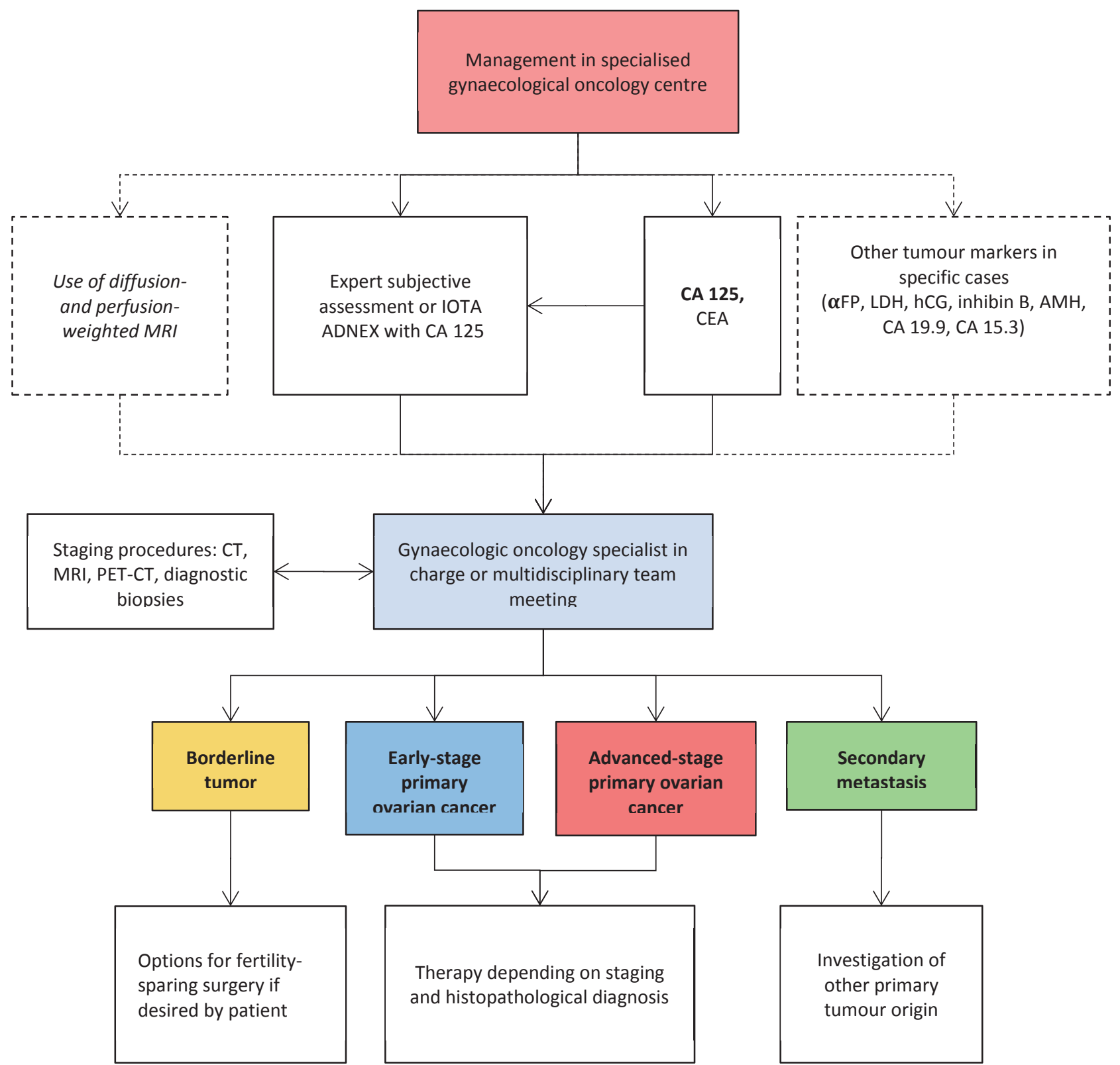

Figure 3: Flowchart of steps necessary to differentiate between subgroups of malignancy and extent of disease within gynaecological oncology centres. *Early stage and advanced stage might differ according to different ADNEX models (Stage I vs Stages II-IV) and oncologically (Stages I-II vs Stages I-IV). $\alpha F P$, alpha-fetoprotein; AMH, anti-Müllerian hormone; CA 125, cancer antigen 125; CA 15-3, cancer antigen 15-3; CA 19.9, carbohydrate antigen 19-9; CEA, carcinoembryonic antigen; CT, computed tomography; hCG, human chorionic gonadoptrophin; IOTA ADNEX, International Ovarian Tumour Analysis Group Assessment of Different Neoplasias in the adneXa; $L D H$, lactate dehydrogenase; MRI, magnetic resonance imaging; PET-CT, positron emission tomography-computed tomography.

\section{Authors}

D. Timmerman, Department of Development and Regeneration, KU Leuven, Leuven, Belgium; Department of Obstetrics and Gynaecology, University Hospitals Leuven, Leuven, Belgium.

F. Planchamp, Clinical Research Unit, Institut Bergonie, Bordeaux, France.

T. Bourne, Department of Development and Regeneration, KU Leuven, Leuven, Belgium; Department of Obstetrics and Gynaecology, University Hospitals Leuven, Leuven, Belgium; Department of Metabolism, Digestion and Reproduction, Queen Charlotte's \& Chelsea Hospital, Imperial College, London, UK.
C. Landolfo, Department of Woman, Child and Public Health, Fondazione Policlinico Universitario A. Gemelli IRCCS, Rome, Italy.

A. du Bois, Department of Gynaecology and Gynaecological Oncology, Evangelische Kliniken EssenMitte, Essen, Germany.

L. Chiva, Department of Gynaecology and Obstetrics, University Clinic of Navarra, Madrid, Spain.

D. Cibula, Department of Obstetrics and Gynaecology, First Faculty of Medicine, Charles University, General University Hospital in Prague, Prague, Czech Republic. 
N. Concin, Department of Gynaecology and Gynaecological Oncology, Evangelische Kliniken Essen-Mitte, Essen, Germany; Department of Obstetrics and Gynaecology, Medical University of Innsbruck, Innsbruck, Austria.

D. Fischerova, Department of Obstetrics and Gynaecology, First Faculty of Medicine, Charles University, General University Hospital in Prague, Prague, Czech Republic.

W. Froyman, Department of Obstetrics and Gynaecology, University Hospitals KU Leuven, Leuven, Belgium

G. Gallardo, Department of Radiology, University Clinic of Navarra, Madrid, Spain.

B. Lemley, Patient Representative, President of Kræfti Underlivet (KIU), Denmark; Chair Clinical Trial Project of the European Network of Gynaecological Cancer Advocacy Groups, ENGAGe.

A. Loft, Department of Clinical Physiology, Nuclear Medicine \& PET, Rigshospitalet, Copenhagen University Hospital, Copenhagen, Denmark.

L. Mereu, Department of Gynaecology and Obstetrics, Gynaecologic Oncology Unit, Santa Chiara Hospital, Trento, Italy.

P. Morice, Department of Gynaecological Surgery, Institut Gustave Roussy, Villejuif, France.

D. Querleu, Division of Gynaecologic Oncology, Fondazione Policlinico Universitario A Gemelli IRCCS, Rome, Italy; Department of Obstetrics and Gynaecologic Oncology, University Hospital, Strasbourg, France.

C. Testa, Department of Woman, Child and Public Health, Fondazione Policlinico Universitario A. Gemelli IRCCS, Rome, Italy; Institute of Obstetrics and Gynaecology, Università Cattolica del Sacro Cuore, Rome, Italy.

I. Vergote, Department of Obstetrics and Gynaecology and Gynaecologic Oncology, University Hospital Leuven, Leuven Cancer Institute, Leuven, Belgium.

V. Vandecaveye, Department of Radiology, University Hospitals Leuven, Leuven Belgium; Division of Translational MRI, Department of Imaging \& Pathology KU Leuven, Leuven, Belgium.

G. Scambia, Department of Woman, Child and Public Health, Fondazione Policlinico Universitario A. Gemelli IRCCS, Rome, Italy; Institute of Obstetrics and Gynaecology, Università Cattolica del Sacro Cuore, Rome, Italy.

C. Fotopoulou, Department of Gynaecologic Oncology, Hammersmith Hospital, Imperial College, London, UK.
Initiated through ESGO, the decision to develop multidisciplinary consensus statements was made jointly by ESGO, ISUOG, IOTA and ESGE. ESGO provided administrative support. ESGO, ISUOG, IOTA and ESGE are non-profit-making professional societies. The development group (including all authors) is responsible collectively for the decision to submit for publication. Christina Fotopoulou (chair), Dirk Timmerman (chair) and François Planchamp (methodologist) wrote the first draft of the manuscript. All other contributors actively gave personal input, reviewed the manuscript and gave final approval before submission.

Acknowledgments: The authors thank ESGO, ISUOG, IOTA, and ESGE for their support. We wish also to express sincere gratitude to Maciej Malecki (University Hospital Leuven, Leuven, Belgium) for providing technical support during the conference call.

Funding: All costs relating to the development process were covered from ESGO, ISUOG, IOTA, and ESGE funds. There was no external funding of the development process or manuscript production.

Disclosures: D.T.: senior investigator for FWO (Fund for Scientific Research Flanders) and research sponsored by Roche Diagnostics. KU Leuven has consultancy agreements with GE Healthcare, Samsung Healthcare, GSK and Canon. T.B.: research sponsored by Roche Diagnostics, Samsung Medison and Illumina, and grants for traveling from Samsung Medison. L.C.: advisory boards for AstraZeneca, GSK, Takeda and Roche. D.C.: advisory boards for Genmab, AstraZeneca, Roche and Sotio. N.C.: advisory boards for AstraZeneca, Seattle Genetics, Mersana and eTheRNA Immunotherapies NV, grants for traveling from Roche, Genmab and Amgen, and educational fees from MSD and Medscape Oncology. A.d.B.: advisory boards for Roche, AstraZeneca, GSK/Tesaro, BIOCAD, Clovis, Genmab/ Seattle Genetics, Pfizer and Amgen, and grants for traveling from Roche and AstraZeneca. I.V.: consulting activities for Amgen, AstraZeneca, Clovis Oncology, Carrick Therapeutics, Debiopharm International SA, Deciphera Pharmaceuticals, Elevar Therapeutics, F. Hoffmann-La Roche Ltd, Genmab, GSK, Immunogen Inc, Medical University of Vienna, Mersana, Millenium Pharmaceuticals, MSD, Novocure, Octimet Oncology NV, Oncoinvent AS, Pharmamar, Sotio a.s. Prague, Tesaro Inc, Verastem Oncology and Zentalis, contracted research (via KU Leuven) from Oncoinvent AS and Genmab, grants (corporate sponsored research) from Amgen and Roche, and accommodation/travel expenses from Amgen, MSD, Tesaro, AstraZeneca and Roche. C.F.: advisory boards for Roche, GSK, Tesaro, AZ/MSD, Clovis, Sequana and Ethicon, and grants for traveling from GSK and Roche. F.P., C.L., D.F., W.F., G.G., B.L., A.L., L.M., P.M., D.Q., A.T., V.V. and G.S. report no conflicts of interest. 
Appendix 1: Identification of scientific evidence: literature search in MEDLINE.

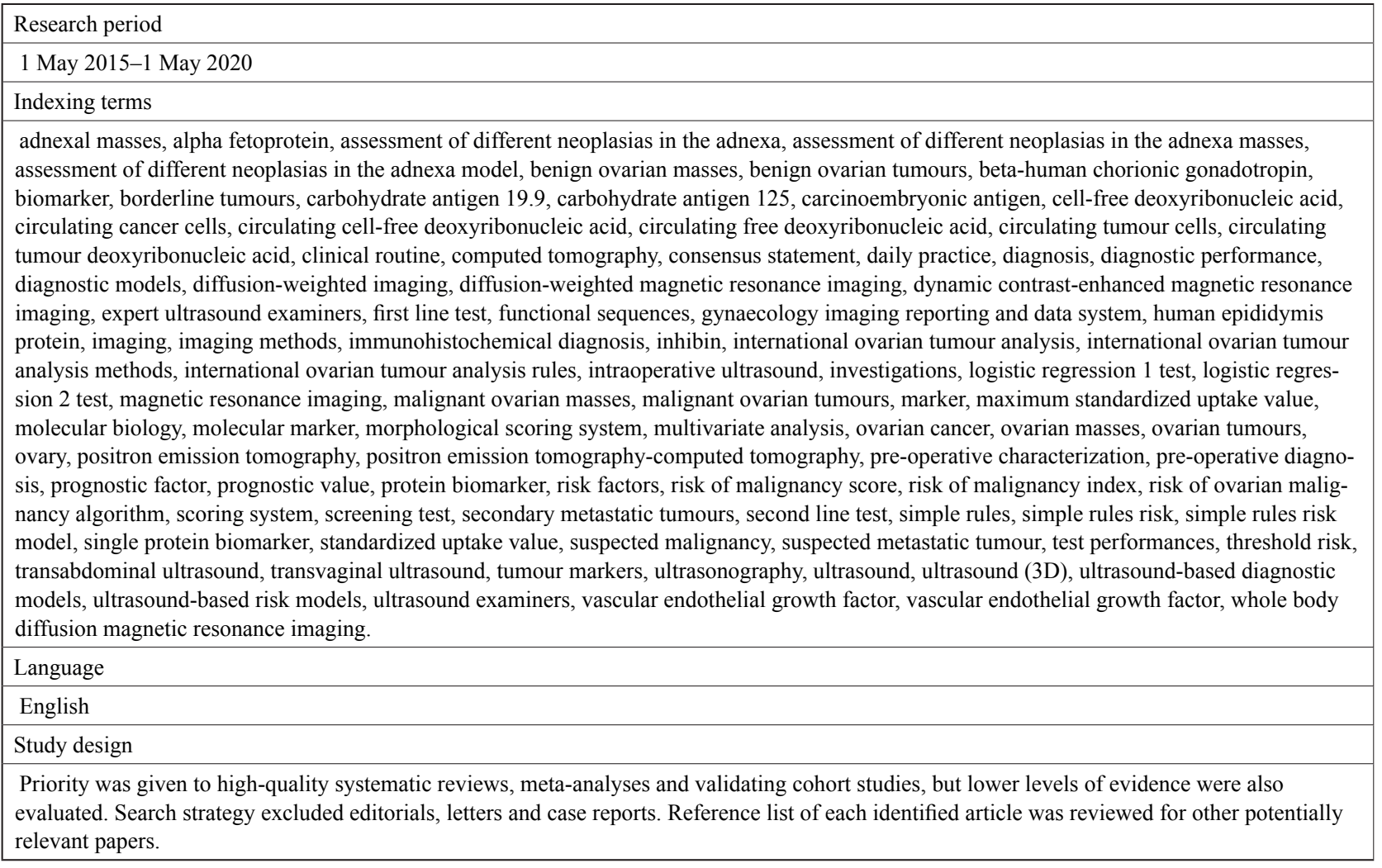

\section{References}

Ahmed SA, Abou-Taleb H, Yehia A et al. The accuracy of multi-detector computed tomography and laparoscopy in the prediction of peritoneal carcinomatosis index score in primary ovarian cancer. Acad Radiol. 2019;26:1650-8.

Akturk E, Karaca RE, Alanbay I et al. Comparison of four malignancy risk indices in the detection of malignant ovarian masses. J Gynecol Oncol. 2011;22:177-82.

Al Musalhi K, Al Kindi M, Al Aisary F et al. Evaluation of HE4, CA-125, Risk of Ovarian Malignancy Algorithm (ROMA) and Risk of Malignancy Index (RMI) in the preoperative assessment of patients with adnexal mass. Oman Med J. 2016;31:336-44.

Alcazar JL, Pascual MA, Graupera B et al. External validation of IOTA simple descriptors and simple rules for classifying adnexal masses. Ultrasound Obstet Gynecol. 2016;48:397-402.

Alcazar JL, Pascual MA, Olartecoechea B et al. IOTA simple rules for discriminating between benign and malignant adnexal masses: prospective external validation. Ultrasound Obstet Gynecol. 2013;42:467-71.

Al-Musalhi K, Al-Kindi M, Ramadhan F et al. Validity of Cancer Antigen-125 (CA-125) and Risk of Malignancy Index (RMI) in the diagnosis of ovarian cancer. Oman Med J. 2015;30:428-34.

American College of Obstetricians and Gynecologists' Committee on practice bulletins - Gynecology. Practice Bulletin No. 174: Evaluation and Management of Adnexal Masses. Obstet Gynecol. 2016;128:210-26.

Ameye L, Timmerman D, Valentin L et al. Clinically oriented three-step strategy for assessment of adnexal pathology. Ultrasound Obstet Gynecol. 2012;40:582-91.

Amor F, Alcazar JL, Vaccaro H et al. GI-RADS reporting system for ultrasound evaluation of adnexal masses in clinical practice: a prospective multicenter study. Ultrasound Obstet Gynecol. 2011;38:450-5.

Amor F, Vaccaro H, Alcazar JL et al. Gynecologic imaging reporting and data system: a new proposal for classifying adnexal masses on the basis of sonographic findings. J Ultrasound Med. 2009;28:285-91.

Andreotti RF, Timmerman D, Benacerraf BR et al. Erratum. Ovarian-adnexal reporting lexicon for ultrasound: A white paper of the ACR ovarian-adnexal reporting and data system committee. J Am Coll Radiol. 2019;16:403-6.

Andreotti RF, Timmerman D, Benacerraf BR et al. Ovarianadnexal reporting lexicon for ultrasound: A white paper of the ACR ovarian-adnexal reporting and data system committee. J Am Coll Radiol. 2018;15:1415-29.

Andreotti RF, Timmerman D, Strachowski LM et al. O-RADS US risk stratification and management system: A consensus guideline from the ACR ovarian-adnexal reporting and data system committee. Radiology. 2020;294:168-85.

Anfelter P, Testa A, Chiappa V et al. Corrigendum. Imaging in gynecological disease (17): ultrasound features of malignant ovarian yolk sac tumors (endodermal sinus tumors). Ultrasound Obstet Gynecol. 2020;56:966.

Anfelter P, Testa A, Chiappa V et al. Imaging in gynecological disease (17): ultrasound features of malignant ovarian yolk sac tumors (endodermal sinus tumors). Ultrasound Obstet Gynecol. 2020;56:276-84.

Anton C, Carvalho FM, Oliveira EI et al. A comparison of CA125, HE4, risk ovarian malignancy algorithm (ROMA), and risk malignancy index (RMI) for the classification of ovarian masses. Clinics (Sao Paulo). 2012;67:437-41.

Araujo KG, Jales RM, Pereira PN et al. Performance of the IOTA ADNEX model in preoperative discrimination of adnexal masses in a gynecological oncology center. Ultrasound Obstet Gynecol. 2017;49:778-83. 
Avesani G, Arshad M, Lu H et al. Radiological assessment of peritoneal cancer index on preoperative $\mathrm{CT}$ in ovarian cancer is related to surgical outcome and survival. Radiol Med. 2020;125:770-6.

Axtell AE, Lee MH, Bristow RE et al. Multi-institutional reciprocal validation study of computed tomography predictors of suboptimal primary cytoreduction in patients with advanced ovarian cancer. J Clin Oncol. 2007;25:384-9.

Babic A, Cramer DW, Kelemen LE et al. Predictors of pretreatment CA125 at ovarian cancer diagnosis: a pooled analysis in the Ovarian Cancer Association Consortium. Cancer Causes Control. 2017;28:459-68.

Barbosa A, Peixoto A, Pinto P et al. Potential clinical applications of circulating cell-free DNA in ovarian cancer patients. Expert Rev Mol Med. 2018;20:6.

Basha MAA, Metwally MI, Gamil SA et al. Comparison of O-RADS, GI-RADS, and IOTA simple rules regarding malignancy rate, validity, and reliability for diagnosis of adnexal masses. Eur Radiol. 2021;31:674-84.

Basha MAA, Refaat R, Ibrahim SA et al. Gynecology Imaging Reporting and Data System (GI-RADS): diagnostic performance and inter-reviewer agreement. Eur Radiol. 2019;29:5981-90.

Behnamfar F, Adibi A, Khadra H et al. Diagnostic accuracy of gynecology imaging reporting and data system in evaluation of adnexal lesions. J Res Med Sci. 2019;24:57.

Bouzari Z, Yazdani S, Shirkhani Kelagar Z et al. Risk of malignancy index as an evaluation of preoperative pelvic mass. Caspian J Intern Med. 2011;2:331-5.

Bozkurt M, Yumru AE, Aral I. Evaluation of the importance of the serum levels of CA-125, CA15-3, CA-19-9, carcinoembryonic antigen and alpha fetoprotein for distinguishing benign and malignant adnexal masses and contribution of different test combinations to diagnostic accuracy. Eur J Gynaecol Oncol. 2013;34:540-4.

Bristow RE, Duska LR, Lambrou NC et al. A model for predicting surgical outcome in patients with advanced ovarian carcinoma using computed tomography. Cancer. 2000;89:1532-40.

Byrom J, Widjaja E, Redman CW et al. Can pre-operative computed tomography predict resectability of ovarian carcinoma at primary laparotomy? BJOG. 2002;109:369-75.

Cao H, You D, Lan Z et al. Prognostic value of serum and tissue HE4 expression in ovarian cancer: a systematic review with meta-analysis of 90 studies. Expert Rev Mol Diagn. 2018;18:371-83.

Carter JS, Koopmeiners JS, Kuehn-Hajder JE et al. Quantitative multiparametric MRI of ovarian cancer. J Magn Reson Imaging. 2013;38:1501-9.

Castellucci P, Perrone AM, Picchio $M$ et al. Diagnostic accuracy of $18 \mathrm{~F}-\mathrm{FDG} \mathrm{PET} / \mathrm{CT}$ in characterizing ovarian lesions and staging ovarian cancer: correlation with transvaginal ultrasonography, computed tomography, and histology. Nucl Med Commun. 2007;28:589-95.

Chacon E, Dasi J, Caballero C et al. Risk of Ovarian Malignancy Algorithm versus Risk Malignancy Index-I for preoperative assessment of adnexal masses: A systematic review and meta-analysis. Gynecol Obstet Invest. 2019;84:591-8

Chen Q, Zhang ZH, Wang S et al. Circulating cell-free DNA or circulating tumor DNA in the management of ovarian and endometrial Cancer. Onco Targets Ther. 2019;12:11517-30.

Chen X, Zhou H, Chen R et al. Development of a multimarker assay for differential diagnosis of benign and malignant pelvic masses. Clin Chim Acta. 2015;440:57-63.

Choi HJ, Lee YY, Sohn I et al. Comparison of CA 125 alone and risk of ovarian malignancy algorithm (ROMA) in patients with adnexal mass: A multicenter study. Curr Probl Cancer. 2020;44:100508.

Chopra S, Vaishya R, Kaur J. An Evaluation of the applicability of the Risk of Malignancy Index for adnexal masses to patients seen at a tertiary Hospital in Chandigarh, India. J Obstet Gynaecol India. 2015;65:405-10.
Cramer DW, Vitonis AF, Welch WR et al. Correlates of the preoperative level of CA125 at presentation of ovarian cancer. Gynecol Oncol. 2010;119:462-8.

Cui R, Wang Y, Li Y. Clinical value of ROMA index in diagnosis of ovarian cancer: meta-analysis. Cancer Manag Res. 2019;11:2545-51.

Dai G, Liang K, Xiao Z et al. A meta-analysis on the diagnostic value of diffusion-weighted imaging on ovarian cancer. J BUON. 2019;24:2333-40.

Dauwen H, Van Calster B, Deroose CM et al. PET/CT in the staging of patients with a pelvic mass suspicious for ovarian cancer. Gynecol Oncol. 2013;131:694-700.

Demidov VN, Lipatenkova J, Vikhareva $\mathrm{O}$ et al. Imaging of gynecological disease (2): clinical and ultrasound characteristics of Sertoli cell tumors, Sertoli-Leydig cell tumors and Leydig cell tumors. Ultrasound Obstet Gynecol. 2008;31:85-91.

Dierickx I, Valentin L, Van Holsbeke $\mathrm{C}$ et al. Imaging in gynecological disease (7): clinical and ultrasound features of Brenner tumors of the ovary. Ultrasound Obstet Gynecol. 2012;40:706-13

Dirrichs $\mathrm{T}$, Bauerschlag $\mathrm{D}$, Maass $\mathrm{N}$ et al. Impact of Multiparametric MRI (mMRI) on the therapeutic management of adnexal masses detected with Transvaginal Ultrasound (TVUS): An interdisciplinary management approach. Acad Radiol. 2020;1076-6332:30652-8.

Dochez V, Randet M, Renaudeau C et al. Efficacy of HE4, CA125, Risk of Malignancy Index and Risk of Ovarian Malignancy Index to detect ovarian cancer in women with presumed benign ovarian tumours: A prospective, multicentre trial. J Clin Med. 2019;8:1784.

Dohan A, Hoeffel C, Soyer P et al. Evaluation of the peritoneal carcinomatosis index with CT and MRI. Br J Surg. 2017;104:1244-9.

Dowdy SC, Mullany SA, Brandt KR et al. The utility of computed tomography scans in predicting suboptimal cytoreductive surgery in women with advanced ovarian carcinoma. Cancer. 2004; 101:346-52.

$\mathrm{du}$ Bois A, Rochon J, Pfisterer J et al. Variations in institutional infrastructure, physician specialization and experience, and outcome in ovarian cancer: a systematic review. Gynecol Oncol. 2009;112:422-36.

Education and Practical Standards Committee, European Federation of Societies for Ultrasound in Medicine and Biology. Minimum training recommendations for the practice of medical ultrasound. Ultraschall Med. 2006;27:79-105.

Elit LM, Bondy SJ, Paszat LP et al. Surgical outcomes in women with ovarian cancer. Can J Surg. 2008;51:346-54.

Engelen MJ, Kos HE, Willemse PH et al. Surgery by consultant gynecologic oncologists improves survival in patients with ovarian carcinoma. Cancer. 2006;106:589-98.

Espada M, Garcia-Flores JR, Jimenez M et al. Diffusionweighted magnetic resonance imaging evaluation of intra-abdominal sites of implants to predict likelihood of suboptimal cytoreductive surgery in patients with ovarian carcinoma. Eur Radiol. 2013;23:2636-42.

Esquivel J, Chua TC, Stojadinovic A et al. Accuracy and clinical relevance of computed tomography scan interpretation of peritoneal cancer index in colorectal cancer peritoneal carcinomatosis: a multi-institutional study. J Surg Oncol. 2010;102:565-70.

Franchi D, Boveri S, Fruscio R et al. Imaging in gynecological disease (8): ultrasound characteristics of recurrent borderline ovarian tumors. Ultrasound Obstet Gynecol. 2013;41:452-8.

Froyman W, Landolfo C, De Cock B et al. Risk of complications in patients with conservatively managed ovarian tumours (IOTA5): a 2-year interim analysis of a multicentre, prospective, cohort study. Lancet Oncol. 2019;20:448-58.

Gadelhak B, Tawfik AM, Saleh GA et al. Extended abdominopelvic MRI versus $\mathrm{CT}$ at the time of adnexal mass characterization for assessing radiologic peritoneal cancer index (PCI) prior to cytoreductive surgery. Abdom Radiol (NY). 2019;44:2254-61. 
Gemer O, Gdalevich M, Ravid M et al. A multicenter validation of computerized tomography models as predictors of nonoptimal primary cytoreduction of advanced epithelial ovarian cancer. Eur J Surg Oncol. 2009;35:1109-12.

Giannopoulou L, Kasimir-Bauer S, Lianidou ES. Liquid biopsy in ovarian cancer: recent advances on circulating tumor cells and circulating tumor DNA. Clin Chem Lab Med. 2018;56:186-97.

Gity M, Parviz S, Saligheh Rad H et al. Differentiation of benign from malignant adnexal masses by Dynamic Contrast-Enhanced MRI (DCE-MRI): Quantitative and semi-quantitative analysis at 3-Tesla MRI. Asian Pac J Cancer Prev. 2019;20:1073-9.

Glanc P, Benacerraf B, Bourne T et al. First international consensus report on adnexal masses: Management recommendations. J Ultrasound Med. 2017;36:849-63.

Guerriero S, Testa AC, Timmerman D et al. Imaging of gynecological disease (6): clinical and ultrasound characteristics of ovarian dysgerminoma. Ultrasound Obstet Gynecol. 2011;37:596-602.

Guo YX, Neoh KH, Chang XH et al.Diagnostic value of HE4+ circulating tumor cells in patients with suspicious ovarian cancer. Oncotarget. 2018;9:7522-33.

Hada A, Han LP, Chen Y et al. Comparison of the predictive performance of risk of malignancy indexes 1-4, HE4 and risk of malignancy algorithm in the triage of adnexal masses. J Ovarian Res. 2020;13:46.

Hartman CA, Juliato CR, Sarian LO et al. Ultrasound criteria and CA 125 as predictive variables of ovarian cancer in women with adnexal tumors. Ultrasound Obstet Gynecol. 2012;40:360-6.

$\mathrm{He}$ M, Song Y, Li H et al. Histogram analysis comparison of monoexponential, advanced diffusion-weighted imaging, and dynamic contrast-enhanced MRI for differentiating borderline from malignant epithelial ovarian tumors. J Magn Reson Imaging. 2020;52:257-68.

Huang J, Chen J, Huang Q. Diagnostic value of HE4 in ovarian cancer: A meta-analysis. Eur J Obstet Gynecol Reprod Biol. 2018;231:35-42

Huy NVQ, Van Khoa V, Tam LM et al. Standard and optimal cut-off values of serum ca-125, HE4 and ROMA in preoperative prediction of ovarian cancer in Vietnam. Gynecol Oncol Rep. 2018;25:110-4.

Jacob F, Meier M, Caduff R et al. No benefit from combining HE4 and CA125 as ovarian tumor markers in a clinical setting. Gynecol Oncol. 2011;121:487-91.

Jacobs I, Oram D et al. A risk of malignancy index incorporating CA 125, ultrasound and menopausal status for the accurate preoperative diagnosis of ovarian cancer. $\mathrm{Br} \mathrm{J}$ Obstet Gynaecol. 1990;97:922-9.

Javdekar R, Maitra N. Risk of Malignancy Index (RMI) in Evaluation of Adnexal Mass. J Obstet Gynaecol India. 2015;65:117-21

Jia MM, Deng J, Cheng XL et al. Diagnostic accuracy of urine HE4 in patients with ovarian cancer: a meta-analysis. Oncotarget. 2017;8:9660-71.

Johnson CC, Kessel B, Riley TL et al. The epidemiology of CA-125 in women without evidence of ovarian cancer in the Prostate, Lung, Colorectal and Ovarian Cancer (PLCO) screening trial. Gynecol Oncol. 2008;110:383-9.

Kaijser J, Sayasneh A, Van Hoorde K et al. Presurgical diagnosis of adnexal tumours using mathematical models and scoring systems: a systematic review and meta-analysis. Hum Reprod Update. 2014;20:449-62.

Kaijser J, Van Gorp T, Sayasneh A et al. Differentiating stage I epithelial ovarian cancer from benign disease in women with adnexal tumors using biomarkers or the ROMA algorithm. Gynecol Oncol. 2013;130:398-9.

Kaijser J, Van Gorp T, Smet ME et al. Are serum HE4 or ROMA scores useful to experienced examiners for improving characterization of adnexal masses after transvaginal ultrasonography? Ultrasound Obstet Gynecol. 2014;43: 8997.
Kaijser J, Vandecaveye V, Deroose CM et al. Imaging techniques for the pre-surgical diagnosis of adnexal tumours. Best Pract Res Clin Obstet Gynaecol. 2014;28:683-95.

Kelly PJ, Archbold P, Price JH et al. Serum CA19.9 levels are commonly elevated in primary ovarian mucinous tumours but cannot be used to predict the histological subtype. J Clin Pathol. 2010;63:169-73.

Khoiwal K, Bahadur A, Kumari R et al. Assessment of diagnostic value of serum Ca-125 and risk of Malignancy Index Scoring in the evaluation of adnexal masses. J Midlife Health. 2019;10:192-6.

Kim B, Park Y, Ahn HJ et al. Diagnostic performance of CA 125, HE4, and risk of Ovarian Malignancy Algorithm for ovarian cancer. J Clin Lab Anal. 2019;33:e22624.

Kim HJ, Choi CH, Lee YY et al. Surgical outcome prediction in patients with advanced ovarian cancer using computed tomography scans and intraoperative findings. Taiwan $\mathrm{J}$ Obstet Gynecol. 2014;53:343-7.

Kim SJ, Lee SW. Diagnostic accuracy of (18)F-FDG PET/ CT for detection of peritoneal carcinomatosis; a systematic review and meta-analysis. Br J Radiol. 2018;91:20170519.

Kitajima K, Suzuki K, Senda M et al. FDG-PET/CT for diagnosis of primary ovarian cancer. Nucl Med Commun. 2011:32:549-53.

Knafel A, Banas T, Nocun A et al. The prospective external validation of International Ovarian Tumor Analysis (IOTA). Simple rules in the hands of level I and II examiners. Ultraschall Med. 2016;37:516-23.

Kolostova K, Matkowski R, Jedryka $M$ et al. The added value of circulating tumor cells examination in ovarian cancer staging. Am J Cancer Res 2015; 5: 3363-75.

Koneczny J, Czekierdowski A, Florczak M et al. The use of sonographic subjective tumor assessment, IOTA logistic regression model 1, IOTA simple rules and GI-RADS system in the preoperative prediction of malignancy in women with adnexal masses. Ginekol Pol. 2017;88:647-53.

Kotowicz B, Fuksiewicz M, Sobiczewski P et al. Clinical value of human epididymis protein 4 and the Risk of Ovarian Malignancy Algorithm in differentiating borderline pelvic tumors from epithelial ovarian cancer in early stages. Eur J Obstet Gynecol Reprod Biol. 2015;194:141-6.

Kurman RJ, Carcangiu ML, Herrington S et al. (eds). WHO Classification of tumours of female reproductive organs, 4th edn. IARC: Lyon, 2014.

Laghi A, Bellini D, Rengo M et al. Diagnostic performance of computed tomography and magnetic resonance imaging for detecting peritoneal metastases: systematic review and metaanalysis. Radiol Med. 2017;122:1-15.

Landolfo C, Valentin L, Franchi D et al. Differences in ultrasound features of papillations in unilocular-solid adnexal cysts: a retrospective international multicenter study. Ultrasound Obstet Gynecol. 2018; 52: 269-78.

Li B, Pu K, Ge L et al. Diagnostic significance assessment of the circulating cell-free DNA in ovarian cancer: An updated meta-analysis. Gene. 2019;714:143993.

Li F, Tie R, Chang K et al. Does risk for ovarian malignancy algorithm excel human epididymis protein 4 and CA125 in predicting epithelial ovarian cancer: a meta-analysis. BMC Cancer. 2012;12:258.

Li HM, Feng F, Qiang JW et al. Quantitative dynamic contrastenhanced MR imaging for differentiating benign, borderline, and malignant ovarian tumors. Abdom Radiol (NY) 2018; 43: 3132-41.

Li N, Zuo H, Chen L et al. Circulating tumor cell detection in epithelial ovarian cancer using dual-component antibodies targeting EpCAM and FRalpha. Cancer Manag Res. 2019;11:10939-48.

Lin J, Qin J, Sangvatanakul V. Human epididymis protein 4 for differential diagnosis between benign gynecologic disease and ovarian cancer: a systematic review and metaanalysis. Eur J Obstet Gynecol Reprod Biol. 2013;167:815 . 
Lou E, Vogel RI, Teoh D et al. Assessment of circulating tumor cells as a predictive biomarker of histology in women with suspected ovarian cancer. Lab Med. 2018;49:134-9.

Low RN, Barone RM, Lucero J. Comparison of MRI and CT for predicting the Peritoneal Cancer Index (PCI) preoperatively in patients being considered for cytoreductive surgical procedures. Ann Surg Oncol. 2015;22:1708-15.

$\mathrm{Lu} \mathrm{H}$, Arshad M, Thornton A et al. A mathematical-descriptor of tumor-mesoscopic-structure from computed-tomography images annotates prognostic- and molecular-phenotypes of epithelial ovarian cancer. Nat Commun 2019;10:764.

Ludovisi M, De Blasis I, Virgilio B et al. Imaging in gynecological disease (9): clinical and ultrasound characteristics of tubal cancer. Ultrasound Obstet Gynecol. 2014;43: 328-35

Lycke M, Kristjansdottir B, Sundfeldt K. A multicenter clinical trial validating the performance of HE4, CA125, risk of ovarian malignancy algorithm and risk of malignancy index. Gynecol Oncol. 2018;151:159-65.

Malek M, Oghabian Z, Tabibian E et al. Comparison of qualitative (Time Intensity Curve Analysis), semiquantitative, and quantitative multi-phase 3T DCEMRI parameters as predictors of malignancy in adnexal. Asian Pac J Cancer Prev. 2019;20:1603-11.

Marin D, Catalano C, Baski M et al. 64-Section multidetector row $\mathrm{CT}$ in the preoperative diagnosis of peritoneal carcinomatosis: correlation with histopathological findings. Abdom Imaging. 2010;35:694-700.

Medeiros LR, Rosa DD, da Rosa MI et al. Accuracy of CA 125 in the diagnosis of ovarian tumors: a quantitative systematic review. Eur J Obstet Gynecol Reprod Biol. 2009;142:99_ 105

Melo A, Verissimo R, Farinha $\mathrm{M}$ et al. Discriminative value of CA-125, HE4, Risk of Malignancy Index II (RMI-II) and Risk of Malignancy Algorithm (ROMA) in the differential diagnosis of pelvic masses: conclusions from a referral Centre in Portugal. J Obstet Gynaecol. 2018;38:1140-5.

Meng XF, Zhu SC, Sun SJ et al. Diffusion weighted imaging for the differential diagnosis of benign vs. malignant ovarian neoplasms. Oncol Lett. 2016;11:3795-802.

Meys EM, Kaijser J, Kruitwagen RF et al. Subjective assessment versus ultrasound models to diagnose ovarian cancer: A systematic review and meta-analysis. Eur J Cancer. 2016;58:17-29.

Meys EMJ, Jeelof LS, Achten NMJ et al. Estimating risk of malignancy in adnexal masses: external validation of the ADNEX model and comparison with other frequently used ultrasound methods. Ultrasound Obstet Gynecol. 2017;49:784-92.

Michielsen K, Dresen R, Vanslembrouck R et al. Diagnostic value of whole body diffusion-weighted MRI compared to computed tomography for pre-operative, assessment of patients suspected for ovarian cancer. Eur J Cancer. 2017;83:88-98.

Michielsen K, Vergote I, Op de Beeck K et al. Whole-body MRI with diffusion-weighted sequence for staging of patients with suspected ovarian cancer: a clinical feasibility study in comparison to CT and FDG-PET/CT. Eur Radiol. 2014;24:889-901.

Migda M, Bartosz M, Migda MS et al. Diagnostic value of the gynecology imaging reporting and data system (GI-RADS) with the ovarian malignancy marker CA-125 in preoperative adnexal tumor assessment. J Ovarian Res. 2018;11:92.

Moore RG, Brown AK, Miller MC et al. The use of multiple novel tumor biomarkers for the detection of ovarian carcinoma in patients with a pelvic mass. Gynecol Oncol. 2008; 108:402-8.

Moro F, Baima Poma C, Zannoni GF et al. Imaging in gynecological disease (12): clinical and ultrasound features of invasive and non-invasive malignant serous ovarian tumors. Ultrasound Obstet Gynecol. 2017; 50: 788-99.

Moro F, Castellano LM, Franchi D et al. Imaging in gynecological disease: clinical and ultrasound characteristics of ovarian embryonal carcinomas, non-gestational choriocarcinomas and malignant mixed germ cell tumors. Ultrasound Obstet Gynecol 2020.

Moro F, Magoga G, Pasciuto T et al. Imaging in gynecological disease (13): clinical and ultrasound characteristics of endometrioid ovarian cancer. Ultrasound Obstet Gynecol. 2018; 52: 535-43.

Moro F, Zannoni GF, Arciuolo D et al. Imaging in gynecological disease (11): clinical and ultrasound features of mucinous ovarian tumors. Ultrasound Obstet Gynecol. 2017;50:26170.

Nam EJ, Yun MJ, Oh YT et al. Diagnosis and staging of primary ovarian cancer: correlation between PET/CT, Doppler US, and CT or MRI. Gynecol Oncol. 2010;116:389-94.

Nasser S, Lazaridis A, Evangelou M et al. Correlation of preoperative CT findings with surgical \& histological tumor dissemination patterns at cytoreduction for primary advanced and relapsed epithelial ovarian cancer: A retrospective evaluation. Gynecol Oncol. 2016;143:264-9.

Nelson BE, Rosenfield AT, Schwartz PE. Preoperative abdominopelvic computed tomographic prediction of optimal cytoreduction in epithelial ovarian carcinoma. J Clin Oncol. 1993;11:166-72.

Nunes N, Ambler G, Foo X et al. Comparison of two protocols for the management of asymptomatic postmenopausal women with adnexal tumours - a randomised controlled trial of RMI/ RCOG vs Simple Rules. Br J Cancer. 2017;116:584-91.

Nunes N, Ambler G, Foo X et al. Use of IOTA simple rules for diagnosis of ovarian cancer: meta-analysis. Ultrasound Obstet Gynecol. 2014;44:503-14.

Paladini D, Testa A, Van Holsbeke $\mathrm{C}$ et al. Imaging in gynecological disease (5): clinical and ultrasound characteristics in fibroma and fibrothecoma of the ovary. Ultrasound Obstet Gynecol. 2009;34:188-95.

Pauler DK, Menon U, McIntosh M et al. Factors influencing serum CA125II levels in healthy postmenopausal women. Cancer Epidemiol Biomarkers Prev. 2001;10:489-93.

Phallen J, Sausen M, Adleff V et al. Direct detection of earlystage cancers using circulating tumor DNA. Sci Transl Med. 2017;9:2415.

Piovano E, Cavallero C, Fuso L et al. Diagnostic accuracy and cost-effectiveness of different strategies to triage women with adnexal masses: a prospective study. Ultrasound Obstet Gynecol. 2017;50:395-403.

Pozzati F, Moro F, Pasciuto T et al. Imaging in gynecological disease (14): clinical and ultrasound characteristics of ovarian clear cell carcinoma. Ultrasound Obstet Gynecol 2018;52:792-800.

Querleu D, Planchamp F, Chiva L et al. European Society of Gynaecological Oncology (ESGO) Guidelines for Ovarian Cancer Surgery. Int J Gynecol Cancer. 2017;27:1534-42.

Richards A, Herbst U, Manalang J et al. HE4, CA125, the Risk of Malignancy Algorithm and the Risk of Malignancy Index and complex pelvic masses - a prospective comparison in the pre-operative evaluation of pelvic masses in an Australian population. Aust N Z J Obstet Gynaecol. 2015;55:493-7.

Risum S, Hogdall C, Loft A et al. The diagnostic value of PET/ CT for primary ovarian cancer-a prospective study. Gynecol Oncol. 2007;105:145-9.

Rizzo S, De Piano F, Buscarino V et al. Pre-operative evaluation of epithelial ovarian cancer patients: Role of whole body diffusion weighted imaging MR and CT scans in the selection of patients suitable for primary debulking surgery. A single-centre study. Eur J Radiol. 2020;123:108786.

Romagnolo C, Leon AE, Fabricio ASC et al. HE4, CA125 and risk of ovarian malignancy algorithm (ROMA) as diagnostic tools for ovarian cancer in patients with a pelvic mass: An Italian multicenter study. Gynecol Oncol. 2016;141:303-11.

Royal College of Obstetricians and Gynaecologists. Management of suspected ovarian masses in premenopausal women. Green-top Guideline No. 62, 2011. https://www. rcog.org.uk/globalassets/documents/guidelines/gtg_62.pdf [Accessed 27 October 2020] 
Ruiz de Gauna B, Rodriguez D, Olartecoechea B et al. Diagnostic performance of IOTA simple rules for adnexal masses classification: a comparison between two centers with different ovarian cancer prevalence. Eur J Obstet Gynecol Reprod Biol. 2015;191:10-4.

Rutten MJ, van de Vrie R, Bruining A et al. Predicting surgical outcome in patients with International Federation of Gynecology and Obstetrics stage III or IV ovarian cancer using computed tomography: a systematic review of prediction models. Int J Gynecol Cancer. 2015; 25:407-15.

Sagi-Dain L, Lavie O, Auslander R et al. CEA in evaluation of adnexal mass: retrospective cohort analysis and review of the literature. Int J Biol Markers. 2015;30:394-400.

Sagi-Dain L, Lavie O, Auslander R et al.CA 19-9 in evaluation of adnexal mass: retrospective cohort analysis and review of the literature. Int J Biol Markers. 2015;30:e333-40.

Sandri MT, Bottari F, Franchi D et al. Comparison of HE4, CA125 and ROMA algorithm in women with a pelvic mass: correlation with pathological outcome. Gynecol Oncol. 2013;128:233-8

Savelli L, Testa AC, Timmerman D et al. Imaging of gynecological disease (4): clinical and ultrasound characteristics of struma ovarii. Ultrasound Obstet Gynecol. 2008;32:210-9.

Sayasneh A, Ferrara L, De Cock B et al. Evaluating the risk of ovarian cancer before surgery using the ADNEX model: a multicentre external validation study. Br J Cancer. 2016;115:542-8.

Sayasneh A, Wynants L, Preisler J et al. Multicentre external validation of IOTA prediction models and RMI by operators with varied training. Br J Cancer. 2013;108:2448-54.

Shen F, Lu S, Peng Y et al. Performance of ROMA based on Architect CA 125 II and HE4 values in Chinese women presenting with a pelvic mass: A multicenter prospective study. Clin Chim Acta. 2017;471: 119-25.

Shim SH, Lee SJ, Kim SO et al. Nomogram for predicting incomplete cytoreduction in advanced ovarian cancer patients. Gynecol Oncol. 2015;136:30-6.

Shimada K, Matsumoto K, Mimura T et al. Ultrasound-based logistic regression model LR2 versus magnetic resonance imaging for discriminating between benign and malignant adnexal masses: a prospective study. Int J Clin Oncol. 2018;23:514-21

Shin KH, Kim HH, Kwon BS et al. Clinical Usefulness of Cancer Antigen (CA) 125, Human Epididymis 4, and CA72-4 levels and risk of ovarian malignancy algorithm values for diagnosing ovarian tumors in Korean patients with and without endometriosis. Ann Lab Med. 2020;40:40-7.

Stiekema A, Lok CA, Kenter GG et al. A predictive model combining human epididymal protein 4 and radiologic features for the diagnosis of ovarian cancer. Gynecol Oncol. 2014;132:573-7.

Suh DH, Kim M, Choi JY et al. Circulating tumor cells in the differential diagnosis of adnexal masses. Oncotarget. 2017;8:77195-206.

Szubert S, Wojtowicz A, Moszynski R et al. External validation of the IOTA ADNEX model performed by two independent gynecologic centers. Gynecol Oncol. 2016;142:490-5.

Tanizaki Y, Kobayashi A, Shiro M et al. Diagnostic value of preoperative SUVmax on FDG-PET/CT for the detection of ovarian cancer. Int J Gynecol Cancer. 2014;24:454-60.

Tantipalakorn $\mathrm{C}$, Wanapirak $\mathrm{C}$, Khunamornpong $\mathrm{S}$ et al. IOTA simple rules in differentiating between benign and malignant ovarian tumors. Asian Pac J Cancer Prev. 2014; 15:5123-26.

Terlikowska KM, Dobrzycka B, Witkowska AM et al. Preoperative HE4, CA125 and ROMA in the differential diagnosis of benign and malignant adnexal masses. J Ovarian Res. 2016;9:43.

Testa AC, Ferrandina G, Timmerman D et al. Imaging in gynecological disease (1): ultrasound features of metastases in the ovaries differ depending on the origin of the primary tumor. Ultrasound Obstet Gynecol. 2007;29: 505-11.
Thomassin-Naggara I, Balvay D, Aubert E et al. Quantitative dynamic contrast-enhanced MR imaging analysis of complex adnexal masses: a preliminary study. Eur Radiol. 2012;22:738-45.

Thomassin-Naggara I, Poncelet E, Jalaguier-Coudray A et al. Ovarian-Adnexal Reporting Data System Magnetic Resonance Imaging (O-RADS MRI) Score for risk stratification of sonographically indeterminate adnexal masses. JAMA Netw Open. 2020;3:1919896.

Timmerman D, Ameye L, Fischerova D et al. Simple ultrasound rules to distinguish between benign and malignant adnexal masses before surgery: prospective validation by IOTA group. BMJ. 2010;341:6839.

Timmerman D, Schwarzler P, Collins WP et al. Subjective assessment of adnexal masses with the use of ultrasonography: an analysis of interobserver variability and experience. Ultrasound Obstet Gynecol. 1999;13:11-6.

Timmerman D, Testa AC, Bourne T et al. Logistic regression model to distinguish between the benign and malignant adnexal mass before surgery: a multicenter study by the International Ovarian Tumor Analysis Group. J Clin Oncol. 2005;23:8794-801.

Timmerman D, Testa AC, Bourne T et al. Simple ultrasoundbased rules for the diagnosis of ovarian cancer. Ultrasound Obstet Gynecol. 2008;31:681-90.

Timmerman D, Valentin L, Bourne TH et al. Terms, definitions and measurements to describe the sonographic features of adnexal tumors: a consensus opinion from the International Ovarian Tumor Analysis (IOTA) Group. Ultrasound Obstet Gynecol. 2000;16:500-5.

Timmerman D, Van Calster B, Jurkovic D et al. Inclusion of CA-125 does not improve mathematical models developed to distinguish between benign and malignant adnexal tumors. J Clin Oncol. 2007;25:4194-200.

Timmerman D, Van Calster B, Testa A et al. Predicting the risk of malignancy in adnexal masses based on the Simple Rules from the International Ovarian Tumor Analysis group. Am J Obstet Gynecol. 2016;214:424-37.

Timmerman D. The use of mathematical models to evaluate pelvic masses; can they beat an expert operator? Best Pract Res Clin Obstet Gynaecol. 2004;18:91-104.

Timor-Tritsch IE, Lerner JP, Monteagudo A et al. Transvaginal sonographic markers of tubal inflammatory disease. Ultrasound Obstet Gynecol. 1998;12:56-66.

Torkzad MR, Casta N, Bergman A et al. Comparison between MRI and CT in prediction of peritoneal carcinomatosis index (PCI) in patients undergoing cytoreductive surgery in relation to the experience of the radiologist. J Surg Oncol. 2015; 111:746-51.

Valentin L, Hagen B, Tingulstad S et al. Comparison of 'pattern recognition' and logistic regression models for discrimination between benign and malignant pelvic masses: a prospective cross validation. Ultrasound Obstet Gynecol. 2001;18:357-65.

Valentin L. Prospective cross-validation of Doppler ultrasound examination and gray-scale ultrasound imaging for discrimination of benign and malignant pelvic masses. Ultrasound Obstet Gynecol. 1999;14:273-83.

Van Calster B, Steyerberg EW, Bourne T et al. Flawed external validation study of the ADNEX model to diagnose ovarian cancer. Gynecol Oncol Rep. 2016;18:49-50.

Van Calster B, Valentin L, Froyman W et al. Validation of models to diagnose ovarian cancer in patients managed surgically or conservatively: multicentre cohort study. BMJ. 2020;370:2614

Van Calster B, Van Hoorde K, Valentin L et al. Evaluating the risk of ovarian cancer before surgery using the ADNEX model to differentiate between benign, borderline, early and advanced stage invasive, and secondary metastatic tumours: prospective multicentre diagnostic study. BMJ. 2014:349:5920

Van Calster B. External validation of ADNEX model for diagnosing ovarian cancer: evaluating performance of 
differentiation between tumor subgroups. Ultrasound Obstet Gynecol. 2017;50:406-7.

Van Gorp T, Veldman J, Van Calster B et al. Subjective assessment by ultrasound is superior to the risk of malignancy index (RMI) or the risk of ovarian malignancy algorithm (ROMA) in discriminating benign from malignant adnexal masses. Eur J Cancer. 2012;48:1649-56.

Van Holsbeke C, Domali E, Holland TK et al. Imaging of gynecological disease (3): clinical and ultrasound characteristics of granulosa cell tumors of the ovary. Ultrasound Obstet Gynecol. 2008;31:450-6.

Van Holsbeke C, Van Calster B, Bourne T et al. External validation of diagnostic models to estimate the risk of malignancy in adnexal masses. Clin Cancer Res. 2012;18:815-25.

Van Holsbeke C, Van Calster B, Guerriero S et al. Endometriomas: their ultrasound characteristics. Ultrasound Obstet Gynecol. 2010;35:730-40.

Vanderstichele A, Busschaert P, Smeets D et al. Chromosomal instability in cell-free DNA as a highly specific biomarker for detection of ovarian cancer in women with adnexal masses. Clin Cancer Res. 2017;23:2223-31.

Vernooij F, Heintz P, Witteveen E et al. The outcomes of ovarian cancer treatment are better when provided by gynecologic oncologists and in specialized hospitals: a systematic review. Gynecol Oncol. 2007;105:801-12.

Viora E, Piovano E, Baima Poma $\mathrm{C}$ et al. The ADNEX model to triage adnexal masses: An external validation study and comparison with the IOTA two-step strategy and subjective assessment by an experienced ultrasound operator. Eur J Obstet Gynecol Reprod Biol. 2020;247:207-11.

Virgilio BA, De Blasis I, Sladkevicius P et al. Imaging in gynecological disease (16): clinical and ultrasound characteristics of serous cystadenofibromas in adnexa. Ultrasound Obstet Gynecol. 2019;54: 823-30.

Wang J, Gao J, Yao H et al. Diagnostic accuracy of serum HE4, CA125 and ROMA in patients with ovarian cancer: a metaanalysis. Tumour Biol. 2014;35:6127-38.

Westwood M, Ramaekers B, Lang S et al. Risk scores to guide referral decisions for people with suspected ovarian cancer in secondary care: a systematic review and cost-effectiveness analysis. Health Technol Assess. 2018;22:1-264.

Widschwendter M, Zikan M, Wahl B et al.The potential of circulating tumor DNA methylation analysis for the early detection and management of ovarian cancer. Genome Med. 2017;9:116

Woo YL, Kyrgiou M, Bryant A E et al. Centralisation of services for gynaecological cancer. Cochrane Database Syst Rev. 2012;14.

Wynants L, Timmerman D, Verbakel JY et al. Clinical utility of risk models to refer patients with adnexal masses to specialized oncology care: Multicenter external validation using decision curve analysis. Clin Cancer Res. 2017;23:5082-90.

$\mathrm{Xu} \mathrm{Y}$, Zhong R, He J et al. Modification of cut-off values for HE4, CA125 and the ROMA algorithm for early-stage epithelial ovarian cancer detection: Results from 1021 cases in South China. Clin Biochem. 2016;49:32-40.

Yamamoto Y, Oguri H, Yamada R et al. Preoperative evaluation of pelvic masses with combined 18F-fluorodeoxyglucose positron emission tomography and computed tomography. Int J Gynaecol Obstet. 2008;102:124-7.

Yanaranop M, Anakrat V, Siricharoenthai S et al. Is the Risk of Ovarian Malignancy Algorithm better than other tests for predicting ovarian malignancy in women with pelvic masses? Gynecol Obstet Invest. 2017;82:47-53.

Yanaranop M, Jantarateptewan N, Tiyayon J et al. Significance of serum human epididymis protein 4 and cancer antigen 125 in distinguishing type I and type II epithelial ovarian cancers. Int J Gynecol Cancer. 2018;28:1058-65.

Yazbek J, Raju SK, Ben-Nagi J et al. Effect of quality of gynaecological ultrasonography on management of patients with suspected ovarian cancer: a randomised controlled trial. Lancet Oncol. 2008;9:124-31.

Yu S, Yang HJ, Xie SQ et al. Diagnostic value of HE4 for ovarian cancer: a meta-analysis. Clin Chem Lab Med. 2012;50:1439-46.

Yu Z, Qin S, Wang H. Alter circulating cell-free DNA variables in plasma of ovarian cancer patients. J Obstet Gynaecol Res. 2019;45:2237-42.

Zhang P, Wang C, Cheng L et al. Comparison of HE4, CA125, and ROMA Diagnostic Accuracy: A prospective and multicenter study for Chinese women with epithelial ovarian cancer. Medicine (Baltimore). 2015;94:2402.

Zhang S, Yu S, Hou W, et al. Diagnostic extended usefulness of RMI: comparison of four risk of malignancy index in preoperative differentiation of borderline ovarian tumors and benign ovarian tumors. J Ovarian Res. 2019;12:87.

Zhang T, Li F, Liu J et al. Diagnostic performance of the gynecology imaging reporting and data system for malignant adnexal masses. Int J Gynaecol Obstet. 2017;137:325-31.

Zheng $\mathrm{H}$, Tie $\mathrm{Y}$, Wang $\mathrm{X}$ et al. Assessment of the diagnostic value of using serum CA125 and GI-RADS system in the evaluation of adnexal masses. Medicine (Baltimore). 2019;98:14577.

Zhou Q, Li W, Leng B et al. Circulating Cell Free DNA as the diagnostic marker for ovarian cancer: A systematic review and meta-analysis. PLoS One. 2016;11:0155495.

doi.org/10.52054/FVVO.13.2.016 